\title{
Preliminary Study on the Effect of Nitrogen and Potassium Fertilization on Phytochemical Content Quality of Gynura procumbens
}

\author{
Mohamad Fhaizal Mohamad Bukhori ${ }^{a, b, *}$, Hawa ZE Jaafara , Ali \\ Ghasemzadeh $^{\mathrm{a}}$, Uma Rani Sinniah ${ }^{\mathrm{a}}$, Gayatri Karipaya ${ }^{\mathrm{c}}$ \\ a Department of Crop Science, Faculty of Agriculture, Universiti Putra Malaysia, \\ 43400 Serdang, Selangor, Malaysia; ${ }^{b}$ Biology, Centre for Pre-University Studies, \\ Universiti Malaysia Sarawak, 94300 Kota Samarahan, Sarawak, Malaysia; \\ ${ }^{c}$ Institute of Biological Sciences, Faculty of Science, Universiti Malaya, 50603 \\ Kuala Lumpur, Malaysia
}

Abstract Gynura procumbens is an herbaceous plant. Despite the progressive reports on the pharmacological properties, many are overlooking at the importance of agronomic requirements, such as fertilization, to produce high phytochemical content which have not been conclusively concluded. The study was carried out to examine the effects of $\mathrm{N}$ and $\mathrm{K}$ interaction on physiological and phytochemical quality; to identify compositions of phytochemicals, and to determine marker compounds. Physiological and phytochemical attributes were recorded in three harvests of triplicate samples to exhibit the trend for plant quality, and statistically analyzed. Generally, N and K interaction have affected phytochemical content significantly $(p<0.05)$ with stronger effect on physiological and biochemical attributes $(p<0.01)$. The results have demonstrated that the following combination of fertilizer, $0 \mathrm{~kg} / \mathrm{ha} \mathrm{N}$ and $30 \mathrm{~kg} / \mathrm{ha} \mathrm{K}$; and $90 \mathrm{~kg} / \mathrm{ha} \mathrm{N}$ and $0 \mathrm{~kg} / \mathrm{ha} \mathrm{K}$ are high and low, respectively affecting metabolite content in the plant. Lowest rate of $\mathrm{N}$, moderate of $\mathrm{K}$ had produced significant phytochemical contents. Meanwhile, caffeic acid and kaempferol were demonstrated as marker compounds in this study. Thus, phytochemical content can be further established through the selection of appropriate $\mathrm{N}$ and $\mathrm{K}$ rates and proper abiotic stress interaction.

Keywords: agriculture, Gynura, nitrogen, phytochemical, potassium.

*For correspondence: mbmfhaizal@unimas.my

Received: 16 Nov 2020 Accepted: 1 July 2021

(C) Copyright Bukhori. This article is distributed under the terms of the Creative Commons Attribution License, which permits unrestricted use and redistribution provided that the original author and source are credited.

\section{Introduction}

Nutrient that is taken up beyond plant's requirement would offer no further advantage for growth (Chen et al., 2013). Little is known about the response in secondary metabolism effect. If nitrogen (N) and potassium $(\mathrm{K})$ is taken up below the optimal level, it causes stunting, scleromorphism, and increased root to shoot ratio (Galieni et al., 2015). However, the effects of $\mathrm{N}$ and $\mathrm{K}$ deficiency in secondary metabolism is less known. With limited amount of nutrient available in the environment, plant growth and secondary metabolism may compete for the nutrient, and a trade-off between growth and secondary metabolite synthesis can occur (Caretto et al., 2015). The secondary metabolite synthesis may be at the cost of reducing plant growth, and vice versa. Thus, manipulation of $\mathrm{N}$ and/or $\mathrm{K}$ supply may obtain a balance between plant growth and metabolite synthesis, and provide chances to increase plant yield (Pal et al., 2015), at the same time maintaining the secondary metabolite synthesis. Regulation in secondary 
metabolites synthesis are frequently linked to many aspects of plant's interaction with environment (Figueiredo et al., 2008). Therefore, agronomic factors which influence plant growth may also influence the secondary metabolism. It is important to understand how best to maximize biomass production and secondary metabolite to obtain optimal yield per plant of the active component. Therefore, good agronomic practice especially defining the best nutrient amount for highest yield and active substances is essential. According to Ali et al. (2012), increase in N supply, will increase flower yield, and amount and percentage of active substances. However, the study also reported that increase in $\mathrm{N}$ and $\mathrm{P}$, will increase flower essence but addition of $\mathrm{K}$ will decrease it. The important role of $\mathrm{K}$ in metabolism was shown by $\mathrm{K}$ deficiency will affects the primary and secondary metabolites contents, with important consequences for both mechanical stability and pathogen/pest resistance in crops (Ibrahim et al., 2012). Potassium is important and influencing transmembrane potentials, $\mathrm{pH}$ gradients, long-distance transport, ribosomal function, and changes of enzyme activities (Mohamad Bukhori et al., 2015). The reports have explained various potential metabolic activity under $\mathrm{K}$ influence. However, while all these metabolic activities are depending on $\mathrm{K}$ availability, potential effect of $\mathrm{K}$ on secondary metabolite synthesis is yet to establish. In many aspects, $\mathrm{K}$ affects plants in an opposite way to nitrate, resulting in a complex interrelationship between these two nutrients and yield (Chen et al., 2013). However, data are lacking on the mechanisms by which $\mathrm{N}$ and $\mathrm{K}$ interaction could affect plant growth and secondary metabolite synthesis. Therefore, considering the important of Gynura procumbens (G. procumbens) among local herbal plants and role of $\mathrm{N}$ and $\mathrm{K}$ on plant's active substances, the study was conducted to analyse the effect of selected rate of $\mathrm{N}$ and $\mathrm{K}$ on physiological, biochemical response, and phytochemical profile. The specific objective of the study is to determine the effects of different rates of $\mathrm{N}$ and $\mathrm{K}$ on physiological and biochemical attributes, and phytochemical profile (primary and secondary metabolites) at different age presented by the different harvesting time, to identify the optimum harvesting time for total content of secondary metabolite as established by the secondary metabolite harvest index, to examine the leaves secondary metabolite content under different $\mathrm{N}$ and $\mathrm{K}$ rates and harvest time, and to quantify the phenolic and flavonoid content and determine the phytochemical markers under different $\mathrm{N}$ and $\mathrm{K}$ rates and harvest time.

\section{Materials and methods}

\section{Experimental Design and Treatments}

The study was based on Randomized Complete Block Design. The data was processed using the analysis of variance (ANOVA) and mean differences analysed using Duncan Multiple Range Test (DNMRT) and Pearson's Correlation Coefficients (PCC), SAS ${ }^{\circledR} 9.4$ software. This study was two-factorial experiment. The first factor was four rates of $\mathrm{N}$ at 30 (N30), 60 (N60), 90 (N90) kg N/ha and a control without $\mathrm{N}$ application (N0), which corresponds to respective g/plant applications of $0.36 \mathrm{~g}, 0.72 \mathrm{~g}, 1.08 \mathrm{~g}$ and $0 \mathrm{~g} /$ plant, applied in the form of urea (Hanudin et al., 2012). The $\mathrm{N}$ was split into three fertilization phases (three months), and each phase (each month) was about $33.3 \%$ of total $\mathrm{N}$ applied at the first week of the month. The second factor was plant age at three harvest $(\mathrm{H})$ time, viz. 4, 8 and 12 weeks after treatments (WAT).

\section{Plant Preparation}

The propagation was conducted using cutting from mature stem (10 cm, $\geq 2$ internode) and placed in the seed tray containing uniform mixture of sand: coco-peat $(1: 1 \mathrm{v} / \mathrm{v})$ for rooting purposes (Awang et al., 2009). The regenerated plants (1 month old) were then transferred into polyethylene bags $(25 \mathrm{~cm}$ diameter) containing uniform mixture of soilless medium of coco-peat: burnt paddy husk: well composted chicken manure $(5: 5: 1 \mathrm{v} / \mathrm{v} / \mathrm{v})$ ratio, and left for a month to acclimatize until ready for the treatments (Jaafar et al., 2012). The growing media was at $\mathrm{pH}$ value 5.5 to 7.0 . The greenhouse average temperatures were at 22.9 to $27.2^{\circ} \mathrm{C}$ with relative humidity between 50 and $70 \%$. Meanwhile, the average daytime irradiance was $500 \mu \mathrm{mol} \mathrm{m} \mathrm{m}^{-2} \mathrm{~s}^{-1}$ photosynthetic active radiation.

\section{Maintenance and Sampling}

The plants were watered manually once a day in the morning or when necessary. During very hot, watering was conducted twice or thrice. Each watering was about $500 \mathrm{~mL}$ per plant. Non-chemical pest and disease control was conducted manually at the sight of their presence. Each combined treatment consisted of 27 plants totalling a sum of 108 plants used in the experiment. Three plants per treatment were sampled at each $\mathrm{H}$ time.

\section{Photosynthetic Rate and Stomatal Conductance Rate}

The measurement was obtained fromLI-COR® Environmental with closed infrared gas analyzer. The measurements were carried out between 09:00 to 11:00 a.m. using fully expanded young leaves 
numbered three and four from plant apex to record photosynthetic carbon assimilation rate (Photo) and stomatal conductance to water (Cond). The operation was automatic, and the data were stored in LI6400 console and analyzed by the Photosyn Assistant software. Plants of the different treatments were measured alternately. Prior to use, the system was warmed for $30 \mathrm{~min}$ and calibrated with the ZERO IRGA mode. Two steps are required in the calibration process: first, the initial zeroing process for the built-in flow meter; and second, zeroing process for the infra-red gas analyzer. The measurements used optimal conditions set: $400 \mu \mathrm{mol} / \mathrm{mol} \mathrm{CO}_{2} 30^{\circ} \mathrm{C}$ cuvette temperature, $60 \%$ relative humidity with air flow rate at $500 \mathrm{~cm}^{3} \mathrm{~min}^{-1}$, and modified cuvette condition of $800 \mu \mathrm{mol} / \mathrm{m} / \mathrm{s}$ photosynthetically photon flux density. Several precautions were taken to avoid errors during measurements such as leaf surfaces were cleaned and dried using tissue paper before enclosed in the leaf cuvette. (Ibrahim et al., 2017).

\section{Total Chlorophyll Contents}

Total chlorophyll content (TChIC) was measured using fresh weight basis. Only fresh leaf tissues of the third fully expanded leaves from the top of the individual plant were used in the analysis. Leaf disk of 3 $\mathrm{mm}$ in diameter was obtained using puncher to acquire 15 consistent sizes per treatment per block. The leaf disks were immediately immersed and incubated in $20 \mathrm{~mL}$ of $80 \%$ acetone for homogenization in an aluminum foil-covered glass bottle for approximately $24 \mathrm{~h}$ at $5^{\circ} \mathrm{C}$ until all the green colour had bleached out. Finally, the solution ( $15 \mu \mathrm{L}$ ) was transferred into 96 well plate to determine absorbances of chlorophyll a (Chl a), chlorophyll b (Chl b), and carotenoids (Car) using UV-vis Spectrophotometer at wavelengths of 645,662 and $470 \mathrm{~nm}$ optical density (OD), respectively. Measurements were run in three replicates. The chlorophyll content was calculated as $\mathrm{\mu g} \mathrm{g}^{-1}$ fresh weight as per standard equations recommended (Ibrahim et al., 2017).

$$
\begin{aligned}
& \text { Chl } a=[(12.47 \times \text { OD at } 662)-(3.62 \times \text { OD at } 645) \times 10] /(1000 \times w t) \\
& \text { Chl } b=[(25.06 \times \text { OD at } 645)-(6.50 \times \text { OD at } 662) \times 10] /(1000 \times w t) \\
& \text { Car }=[(1000 \times \text { OD at } 4700-(1.29 \times \text { Chl a })-(53.78 \times C h l b)] / 220
\end{aligned}
$$

\section{Total Carbohydrates Content}

Total carbohydrates content (TCC) was measured using the method described by Anthrone and Hofreiter (Hansen \& Moller, 1975). Samples were weighed $1 \mathrm{~g}$ into $50 \mathrm{~mL}$ conical tube. Sample were hydrolyse by keeping it in boiling Water Bath for $3 \mathrm{~h}$ with $5 \mathrm{~mL}$ of $2.5 \mathrm{M}$ hydrochloric acid and cool to room temperature. Then, the sample were neutralise with solid sodium carbonate until the effervescence ceases. Next, the volume was made up to $50 \mathrm{~mL}$ and centrifuged at $5,000 \mathrm{rpm}$ for $5 \mathrm{~min}$. The supernatant separated and then filtered with filter paper. The $1 \mathrm{~mL}$ of aliquots was taken for analysis. Beforehand, the standards were prepared by taking $0.2,0.4,0.6,0.8$ and $1 \mathrm{~mL}$ of the working standard. The $0.0 \mathrm{~mL}$ serves as blank. The volume was made up to $1 \mathrm{~mL}$ in all tubes including the sample tubes by adding distilled water. Cool the contents of all tubes on ice before adding ice-cold anthrone reagent. Then, $4 \mathrm{~mL}$ of anthrone reagent were added and heated for $8 \mathrm{~min}$ in boiling water bath. The blanks used were absolute methanol. Finally, cool rapidly, then, the solution $(15 \mu \mathrm{L})$ was transferred into 96 well plate and read the sample absorbance at $630 \mathrm{~nm}$ using UV-vis Spectrophotometer. Measurements were run in three replicates. The concentration of TCC was calculated according to the following equation that was obtained from the standard glucose graph: The TCC in the sample was expressed as mg glucose equivalent $\mathrm{g}^{-1}$ dry sample.

$$
\begin{gathered}
y=0.01 x+0.1813 \\
R^{2}=0.995
\end{gathered}
$$

All the reagents were prepared fresh prior to use. Anthrone reagent was prepared by dissolving $200 \mathrm{mg}$ of anthrone in $100 \mathrm{~mL}$ of ice-cold $95 \%$ sulphuric acid. Meanwhile, standard glucose was prepared by preparing the stock of liquid chromatography-grade glucose (G) by dissolving $100 \mathrm{mg}$ in $100 \mathrm{~mL}$ of distilled water. The working standard of glucose were prepared by taking $10 \mathrm{~mL}$ of glucose stock and diluted to $100 \mathrm{~mL}$ with distilled water. The solution was stored refrigerated after adding a few drops of toluene (Ibrahim et al., 2017).

\section{Total Protein Content}

Total protein content (TPrC) was measured using the method described by Lowry (John, 1995). Sample were weight $1 \mathrm{~g}$ into $50 \mathrm{~mL}$ conical tube and extracted with $10 \mathrm{~mL}$ of $100 \%$ methanol at room temperature for $24 \mathrm{~h}$ and centrifuged at 7,000 rpm for $10 \mathrm{~min}$. The supernatant was separated and then filtered with filter paper. Then, $0.2 \mathrm{~mL}$ of extract was pipette out and the volume was made to $1 \mathrm{~mL}$ with distilled water. The $5 \mathrm{~mL}$ of alkaline copper reagent was added to all tubes and allowed it to stand for $10 \mathrm{~min}$. Then, 0.5 $\mathrm{mL}$ of Folin's Ciocalteau reagent was added and incubated in the dark for $30 \mathrm{~min}$. The blanks used were absolute methanol. Finally, the solution $(15 \mu \mathrm{L})$ was transferred into 96 well plates to determine the absorbances. The intensity of the colour developed was read at $660 \mathrm{~nm}$ using UV-vis Spectrophotometer. Measurements were run in three replicates. The concentration of TPrC was 
calculated according to the following equation that was obtained from the standard bovine serum albumin graph: The TPrC in the sample was expressed as $\mathrm{mg}$ bovine serum albumin equivalent $\mathrm{g}^{-1}$ dry sample.

$$
\begin{gathered}
y=0.0621 x+0.1554 \\
R^{2}=0.9904
\end{gathered}
$$

All the reagents were prepared fresh prior to use. Standard bovine serum albumin was prepared by preparing the stock of liquid chromatography-grade bovine serum albumin (BSA) by dissolving $20 \mathrm{mg}$ BSA in $10 \mathrm{~mL}$ of the same diluents for the samples. Then dilute to $200,400,600,800,1,000$ and 1,200 $\mu \mathrm{g} / \mathrm{mL}$ (Ibrahim et al., 2011).

\section{Total Lipid Content}

Total lipid content (TLiC) was measured using the method described by Folch (Shams et al., 2015). Sample were weighed $1 \mathrm{~g}$ into $50 \mathrm{~mL}$ conical tube and extracted with chloroform and methanol $(2: 1, \mathrm{v} / \mathrm{v})$ $(20 \mathrm{~mL})$ for homogenization at room temperature for $24 \mathrm{~h}$ and centrifuged at 7,000 rpm for $10 \mathrm{~min}$. Lipid extract was purified to eliminate some contaminants by pouring the extracts into a beaker through a filter paper containing activated charcoal to remove coloring matters. A clear supernatant was obtained which was then further purified with the use of $0.2 \mathrm{~mL}$ of aqueous $0.9 \%(\mathrm{w} / \mathrm{v})$ sodium chloride. Purified lipids were transferred into evaporated and concentrated dryness at $40^{\circ} \mathrm{C}$, and the residue was weighed. Measurements were run in three replicates. Quantification of crude lipid was performed based on the dry weight determination. The TLiC in the sample was expressed as $\mathrm{mg} \mathrm{g}^{-1}$ dry sample. All the reagents were prepared fresh prior to use (Ibrahim et al., 2017).

\section{Total Phenolic Content}

Total phenolic content (TPC) was measured using the method described by Folin-Ciocalteu colorimetric assay (Lowry et al., 1951). Sample were weight $1 \mathrm{~g}$ into $50 \mathrm{~mL}$ conical tube and extracted with $10 \mathrm{~mL}$ of $100 \%$ methanol at room temperature for $24 \mathrm{~h}$ and centrifuged at 7,000 rpm for $10 \mathrm{~min}$. The supernatant was separated and then filtered with filter paper. Briefly, $1 \mathrm{~mL}$ of extract was pipetted into $15 \mathrm{~mL}$ conical tube and $2 \mathrm{~mL}(10 \% \mathrm{v} / \mathrm{v})$ of Folin-Ciocalteu reagent was added to the sample and incubated for $5 \mathrm{~min}$. Later, $1.6 \mathrm{~mL}(7.5 \%)$ of sodium carbonate solution was added into the sample. The sample mixture was then vortexed and incubated in the dark for one hour at room temperature. The blanks used were absolute methanol. Finally, the solution $(15 \mu \mathrm{L})$ was transferred into 96 well plates to determine the absorbances. Absorbance of the samples was then measured at $760 \mathrm{~nm}$ using UV-vis Spectrophotometer. Measurements were run in three replicates. The concentration of TPC was calculated according to the following equation that was obtained from the standard caffeic acid graph: The TPC in the sample was expressed as mg caffeic acid equivalents $\mathrm{g}^{-1}$ dry sample.

$$
\begin{gathered}
y=0.0098 x+0.0427 \\
R^{2}=0.9942
\end{gathered}
$$

All the reagents were prepared fresh prior to use. Standard caffeic acid was prepared by preparing the stock of liquid chromatography-grade caffeic acid (CA) by dissolving $1 \mathrm{mg}$ in $1 \mathrm{~mL}$ of the same diluents for the samples. Then, dilute to $0.1,0.3,0.6,0.9,1.2,1.5,1.8$ and $2.0 \mathrm{mg} / \mathrm{mL}$ (Ibrahim et al., 2017).

\section{Total Flavonoid Content}

Total flavonoid content (TFC) was measured using the method of aluminum chloride complex colorimetric assay Mongkhonsin et al., 2016). Sample were weighed $1 \mathrm{~g}$ into $50 \mathrm{~mL}$ conical tube and extracted with $10 \mathrm{~mL}$ of $100 \%$ methanol at room temperature for $24 \mathrm{~h}$ and centrifuged at 7,000 rpm for $10 \mathrm{~min}$. The supernatant was separated and then filtered with filter paper. Briefly, $1 \mathrm{~mL}$ of extract was pipetted into 15 $\mathrm{mL}$ conical tube, mixed with $5 \mathrm{~mL}$ of distilled water and $0.3 \mathrm{~mL}$ of $5 \%$ sodium nitrite solution. Mixed well and the mixture allowed to stand for $6 \mathrm{~min}$ and then $0.6 \mathrm{~mL}$ of $10 \%$ aluminum chloride solution was added. After $5 \mathrm{~min}, 2 \mathrm{~mL}$ of $1 \mathrm{M}$ sodium hydroxide was added to the mixture and made up to total volume of $10 \mathrm{~mL}$ with distilled water. The blanks used were absolute methanol. Finally, the solution $(15 \mu \mathrm{L})$ was transferred into 96 well plates to determine the absorbances. Absorbance of the samples was then measured at $510 \mathrm{~nm}$ using UV-vis Spectrophotometer. Measurements were run in three replicates. The concentration of TFC was calculated according to the following equation that was obtained from the standard kaempferol graph: The TFC in the sample was expressed as mg kaempferol equivalents $\mathrm{g}^{-1}$ dry sample.

$$
\begin{gathered}
y=0.0108 x+0.0435 \\
R^{2}=0.9933
\end{gathered}
$$

All the reagents were prepared fresh prior to use. Standard kaempferol was prepared by preparing the stock of liquid chromatography-grade kaempferol $(\mathrm{K})$ by dissolving $1 \mathrm{mg}$ in $1 \mathrm{~mL}$ of the same diluents for 
the samples. Then, dilute to $0.04,0.20,0.40,0.70,0.90,1.10,1.30,1.50$ and $1.80 \mathrm{mg} / \mathrm{mL}$ (Kaewseejan et al., 2015).

\section{Quantification of Phenolics and Flavonoid}

\section{Preparation of Plant Extract}

Sample were weighed $1 \mathrm{~g}$ into $50 \mathrm{~mL}$ conical tube and extracted with $10 \mathrm{~mL}$ of $100 \%$ methanol at room temperature for $24 \mathrm{~h}$, sonicated at normal mode for $5 \mathrm{~min}$ and centrifuged at 7,000 rpm for $10 \mathrm{~min}$. The supernatant was separated and then filtered with filter paper. The methanolic-extract was transferred into evaporated and concentrated dryness at $40^{\circ} \mathrm{C}$ using Rotary Evaporator. It was weighed, redissolved in $1.5 \mathrm{~mL}$ liquid chromatography-grade methanol and filtered through sterile membrane filter, $0.45 \mu \mathrm{m} ; 25$ $\mathrm{mm}$ in $2 \mathrm{~mL}$ amber glass vials and ready for further chromatographic analysis (Kaewseejan \& Siriamornpun, 2015).

\section{Thin Layer Chromatography}

In thin layer chromatography (TLC) analysis, the stationary phase used was $20 \times 20 \mathrm{~cm}, 0.25 \mathrm{~mm}$ plate pre-coated with silica gel $60 \mathrm{~F}_{254}$ on aluminum sheets. The mobile phase used was a mixture of toluene, ethyl acetate and formic acid (5:4:1). Marker or reference compounds used were liquid chromatographygrade caffeic acid, cinnamic acid, chlorogenic acid, gallic acid, ferulic acid and vanillic acid for TPC. Meanwhile, kaempferol, quercetin, myricetin and rutin for TFC. Standard compounds were prepared by preparing the stock of compound by dissolving $1 \mathrm{mg}$ in $1 \mathrm{~mL}$ of liquid chromatography-grade methanol (Ismail et al., 2015). The $10 \mu \mathrm{L}$ of sample and reference compound were applied as $6 \mathrm{~mm}$ band, $2 \mathrm{~mm}$ apart, $10 \mathrm{~mm}$ from the lower, upper, left, and right edges of the plate using microsyringe. In the glass tank, $50 \mathrm{~mL}$ of the developing solvent was poured and allowed to be saturated for 5 to $10 \mathrm{~min}$ in room temperature. Migration (as in linear ascending development) distance of the developing solvent on the plate is $80 \mathrm{~mm}$ from lower edge of the plate or equivalent to the time allowed for the development and maximal separation of the active compounds present in the samples was 15 to 25 min. The plates were then dried at $100^{\circ} \mathrm{C}$ using Forced Draft Oven for 3 to $5 \mathrm{~min}$. Dried plates were visualised by observing under UV light at 254- and 366-nm. Spot detection was done qualitatively. The colour and distance of the unknown spots were compared with reference compound. The retardation factor $\left(R_{\mathrm{f}}\right)$ values were calculated using the formula of migration distance of spot/migration distance of solvent (Ismail et al., 2015).

\section{High-Performance Liquid Chromatography for TPC}

The HPLC-grade purity chemicals and reference compounds such as methanol, acetonitrile, orthophosphoric acid $85 \%$, caffeic acid, cinnamic acid, chlorogenic acid, gallic acid, ferulic acid and vanillic acid were used in the analysis. The linear standard curves were constructed by injecting range of $0.05,0.07,0.09,0.11,0.13,0.15$ and $0.17 \mathrm{mg}$ of caffeic acid $\mathrm{mL}^{-1}$ of methanol. Filtered water was obtained from a Milli-Q Ultrapure Water Purification System. All the reference compound stock solutions were prepared by dissolving $1 \mathrm{mg}$ in $1 \mathrm{~mL}$ of liquid chromatography-grade methanol, filtered through sterile membrane filter, $0.45 \mu \mathrm{m} ; 25 \mathrm{~mm}$ in $2 \mathrm{~mL}$ amber glass vials, and stored at $5^{\circ} \mathrm{C}$. Diluted working solutions were freshly prepared for each analysis (Giedyk, 2011). The system was equipped with Waters ${ }^{\circledR}$ 600E Multisolvent Delivery System, USA consisting of UV/Visible Detector (Waters ${ }^{\circledR} 2489$ ), Degasser $\left(\right.$ Waters $\left.{ }^{\circledR}\right)$, Autosampler (Waters ${ }^{\circledR} 2707$ ) and Waters Empower 3 software was employed in this study. Separation was achieved on reversed phase column [RP-18e $(100 \times 4.6 \mathrm{~mm}$ i.d; $2 \mu \mathrm{m})$, Semiprep, Particle size $0 \mu \mathrm{m}$, Pore size $130 \AA$ ] preceded by $\mathrm{C} 18$ guard column at $40^{\circ} \mathrm{C}$ with diode array detector (DAD) set at 190 to $600 \mathrm{~nm}$ and (0.1\%) orthophosphoric acid 85\% (eluent $A$ ): acetonitrile (eluent B) (90.5:9.5, v/v isocratically) employed as the eluent. Column was washed with $100 \%$ methanol for 10 min, the initial conditions were again applied, the system was monitored for 30 min and the column allowed to equilibrate with $(0.1 \%)$ orthophosphoric acid $85 \%$ : acetonitrile (90.5:9.5, v/v isocratically) for $35 \mathrm{~min}$, being 75 min the total consuming time of run. The temperature of the oven was $40^{\circ} \mathrm{C}$. The flow rate was kept constant at $0.7 \mathrm{ml} \mathrm{min}^{-1}$ and the peaks were simultaneously identified using UV absorbance at $327 \mathrm{~nm}$ for caffeic acid. The injection volume was $1 \mu \mathrm{l}$ (standard compound) and $10 \mu \mathrm{l}$ (sample) for each technical repeat automatically. Quantification was carried out by integration of the peak using external standard method. The procedure was performed separately for each standard (Yi et al., 2016). This method was linear in the range tested and had high linear regression coefficient of $r=0.9936$ between concentrations and peak areas.

\section{High-Performance Liquid Chromatography for TFC}

The HPLC-grade purity chemicals and reference compounds such as methanol, acetonitrile, orthophosphoric acid $85 \%$, kaempferol, quercetin, myricetin and rutin were used in the analysis. The linear standard curves were constructed by injecting range of $0.2,0.3,0.4,0.5$ and $0.6 \mathrm{mg}$ of kaempferol 
$\mathrm{mL}^{-1}$ of methanol. Filtered water was obtained from Milli-Q Ultrapure Water Purification System. All the reference compounds stock solutions were prepared by dissolving $1 \mathrm{mg}$ in $1 \mathrm{~mL}$ of liquid chromatographygrade methanol, filtered through sterile membrane filter, $0.45 \mu \mathrm{m} ; 25 \mathrm{~mm}$ in $2 \mathrm{~mL}$ amber glass vials, and stored at $5^{\circ} \mathrm{C}$. Diluted working solutions were freshly prepared for each analysis (Giedyk, 2011). The system was equipped with Waters ${ }^{\circledR}$ 600E Multisolvent Delivery System, USA consisting of UV/Visible Detector (Waters ${ }^{\circledR}$ 2489), Degasser $\left(\right.$ Waters ${ }^{\circledR}$ ), Autosampler (Waters ${ }^{\circledR}$ 2707) and Waters Empower 3 software was employed in this study. Separation was achieved on reversed phase column [RP-18e (100 x $4.6 \mathrm{~mm}$ i.d; $2 \mu \mathrm{m}$ ), Semiprep, Particle size $0 \mu \mathrm{m}$, Pore size $130 \AA$ ] preceded by $\mathrm{C} 18$ guard column at $40^{\circ} \mathrm{C}$ with diode array detector (DAD) set at 190 to $600 \mathrm{~nm}$ and $(0.03 \mathrm{M}$ ) orthophosphoric acid $85 \%$ (eluent A): methanol (eluent B) $(60: 40$, v/v isocratically) employed as the eluent. Column was washed with $100 \%$ methanol for $10 \mathrm{~min}$, the initial conditions were again applied, the system was monitored for 30 min and the column allowed equilibrating with orthophosphoric acid $85 \%$ : methanol (60:40, v/v isocratically) for $35 \mathrm{~min}$, being $75 \mathrm{~min}$ the total consuming time of run. The temperature of the oven was $35^{\circ} \mathrm{C}$. The flow rate was kept constant at $1 \mathrm{ml} \mathrm{min}^{-1}$ and the peaks were simultaneously identified using UV absorbance at 250 to $360 \mathrm{~nm}$ for kaempferol. The injection volume was $10 \mu \mathrm{l}$ (standard compound and sample) for each technical repeat automatically. Quantification was carried out by integration of the peak using external standard method. The procedure was performed separately for each standard (Shoeva et al., 2016). This method was linear in the range tested and had high linear regression coefficient of $r=0.9953$ between concentrations and peak areas.

\section{Statistical Analysis}

The data were subjected to ANOVA and correlation using SAS ${ }^{\circledR} 9.4$ software. The analysis were done in triplicate and expressed as mean $(n=3) \pm$ standard error (SE) from the dependent treatments (Jaafar et al., 2012). The variables from measurements were analyzed using General Linear Model with $\mathrm{N}$ and $\mathrm{K}$ supply managements. Any differences between treatment means were analysed by two-way analysis and compared using DMRT at $p$ value $\leq 0.05$ levels. The regression model that best fitted the data, evaluated by an F-test, was chosen.

\section{Results}

\section{Photosynthetic Rate}

Generally, Photo was statistically consistent in all treatments and significant in $\mathrm{H}$ time $(\mathrm{p} \leq 0.05)$ (Figure 1). The Photo in NOKO was highest at Week 4. As treatment continued to Week 8, Photo has decreased lower than other treatments. Continuing the treatment to Week 12, the NOK0 recorded the lowest Photo than other treatment at almost $1.5 \mu \mathrm{mol} \mathrm{CO} \mathrm{Cm}^{-2} \mathrm{~s}^{-1}$. The Photo in N0K90 treatment was highest than other treatment at Week 12. Photosynthetic rate was highest in NOKO at Week 4 when plants are young and this continued until Week 8 followed by N0K60, N0K30, N90K90, N0K90, N90K30, N90K0 and N90K60. Measurements of Photo are significantly correlated with Cond at $r=0.600 ; p \leq 0.0001$ by a linear function (Table 1). This is because Photo was decreased with continuing $\mathrm{H}$ time and increasing $\mathrm{N}$ and $\mathrm{K}$ rates. In this experiment, Photo was not significantly affected by $\mathrm{N}$ and $\mathrm{K}$ rates $(\mathrm{p} \geq 0.05)$. Plants in NOKO displayed highest Photo $\left(6.5 \mu \mathrm{mol} \mathrm{CO} \mathrm{m}^{-2} \mathrm{~s}^{-1}\right)$ at Week 4 followed by NOK60 $\left(5.6 \mu \mathrm{mol} \mathrm{CO} \mathrm{Cm}^{-2} \mathrm{~s}^{-1}\right)$, N0K30 $\left(5.5 \mu \mathrm{mol} \mathrm{CO} 2 \mathrm{~m}^{-2} \mathrm{~s}^{-1}\right)$, N90K90 $\left(5 \mu \mathrm{mol} \mathrm{CO} 2 \mathrm{~m}^{-2} \mathrm{~s}^{-1}\right)$, N0K90 $\left(4.5 \mu \mathrm{mol} \mathrm{CO} \mathrm{m}^{-2} \mathrm{~s}^{-1}\right)$, N90K30 (4.4 $\left.\mu \mathrm{mol} \mathrm{CO} 2 \mathrm{~m}^{-2} \mathrm{~s}^{-1}\right)$, N90K0 $\left(2.6 \mu \mathrm{mol} \mathrm{CO} 2 \mathrm{~m}^{-2} \mathrm{~s}^{-1}\right)$ and N90K60 $\left(2.2 \mu \mathrm{mol} \mathrm{CO} \mathrm{m}^{-2} \mathrm{~s}^{-1}\right)$. As plant aged at Week 8 and 12, Photo increased significantly $(p \leq 0.05)$ especially at Week 8 , following this order N90K60, NOK30, N0K60, N90K30, N90K0, N0K0, N90K90 and NOK90 with respective values $10.50 \mu \mathrm{mol} \mathrm{CO}_{2} \mathrm{~m}^{-}$ ${ }^{2} \mathrm{~s}^{-1}, 10.40 \mu \mathrm{mol} \mathrm{CO} \mathrm{m}^{-2} \mathrm{~s}^{-1}, 10.10 \mu \mathrm{mol} \mathrm{CO} \mathrm{m}^{-2} \mathrm{~s}^{-1}, 10 \mu \mathrm{mol} \mathrm{CO} \mathrm{m}^{-2} \mathrm{~s}^{-1}, 9.70 \mu \mathrm{mol} \mathrm{CO} \mathrm{m}^{-2} \mathrm{~s}^{-1}, 9.50 \mu \mathrm{mol}$ $\mathrm{CO}_{2} \mathrm{~m}^{-2} \mathrm{~s}^{-1}, 9.40 \mu \mathrm{mol} \mathrm{CO} 2 \mathrm{~m}^{-2} \mathrm{~s}^{-1}$ and $9 \mu \mathrm{mol} \mathrm{CO} \mathrm{Cm}^{-2} \mathrm{~s}^{-1}$ (Figure 1). The event was because the plants in NOKO had enough $\mathrm{N}$ and $\mathrm{K}$ from the growth media for high photosynthetic capacity and light utilisation. Suggesting NOKO, NOK30 and NOK60 are highly respond to nutrient acquisition and affected by water availability and carbon use efficiency (Wang et al., 2016). In this experiment, Photo decreased with continuing $\mathrm{H}$ time was probably because of $\mathrm{K}$ deficiency with continuing $\mathrm{H}$ time (Ali et al., 2012). Potassium has influenced photosynthetic rate, stomatal conductance, water movements (turgor regulation and osmotic adjustment) and enzyme activation which affects adenosine triphosphate (ATP) production in plants (Chen et al., 2013). Subsequently, the ATP will regulate the rate of photosynthesis (Torres \& Lopez, 2010). 


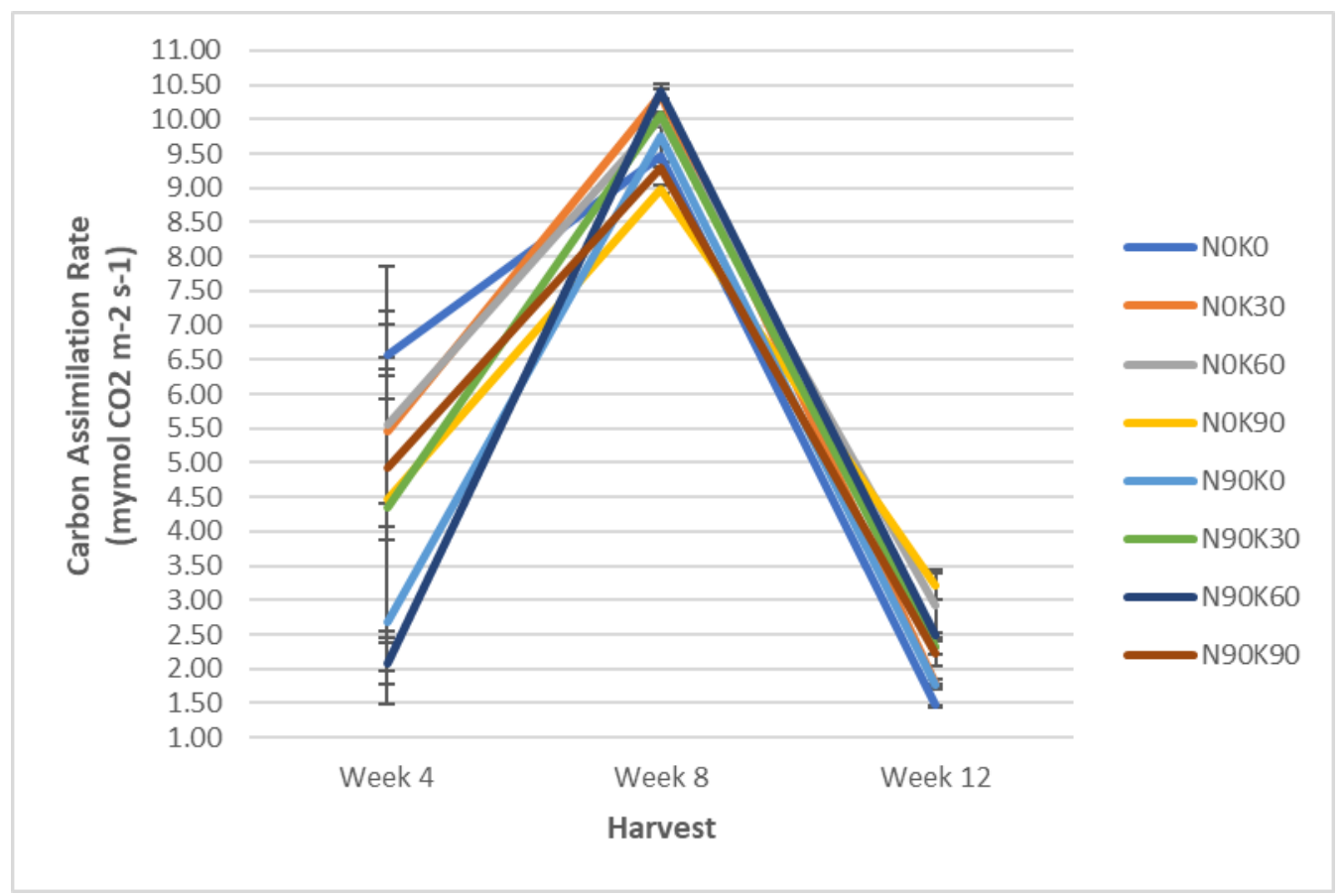

Figure 1. Changes in Photo ( $\left.\mu \mathrm{mol} \mathrm{CO} \mathrm{Cm}^{-2} \mathrm{~s}^{-1}\right)$ as affected by rates of $\mathrm{N}(0$ and $90 \mathrm{~kg} \mathrm{~N} / \mathrm{ha}), \mathrm{K}[0$ (Control), $30,60$ and $90 \mathrm{~kg} \mathrm{~K} / \mathrm{ha}$ ] and $\mathrm{H}$ times (4, 8 and $12 \mathrm{WAT})$. Bars represents standard error of differences between the means. $\mathrm{N}=72$.

\section{Stomatal Conductance Rate}

Generally, Cond was affected in all treatments and statistically significant with increasing age indicated by $\mathrm{H}$ time $(\mathrm{p} \leq 0.0001)$ (Figure 2). The Cond of plants in N0K30 treatment recorded highest value $(p \leq 0.05)$ from Week 4 to Week 12, meanwhile, NOK0 recorded lowest value. As plant aged, Cond in all treatments increased at Week 8 and decreased at Week 12. The Cond in N0K30 was significantly higher $(p \leq 0.0001)$ than other treatments at longer $\mathrm{H}$ time (Week 12). The NOKO has lowest Cond compared to N90K0. Stomatal conductance was highest in N0K30 at Week 8 compared to N90K60 at Week 8. Measurements of Cond are significantly correlated with Photo at $r=0.600 ; p \leq 0.0001$ by a linear function (Table 1 ). In this experiment, Cond seemed to fluctuate with increasing $\mathrm{H}$ time probably because of pre-adaptation, adaptation and post-adaptation during plant growth (Heydarizadeh, 2016). In early stage of growth, stomatal are in pre-adaptation during the acclimatization, therefore Cond was low, following adaptation during the continuous treatment, therefore, Cond was increased, and finally post-adaptation where Cond was decreased during the growth terminal (Wuyts, 2015). The Cond was highest in N0K30 at Week 8, and lowest in other treatments especially when plant aged at Week 12 (Figure 2). Plants in NOK0 probably had the lowest intercellular $\mathrm{CO}_{2}$ concentration $\left(116 \mathrm{~mol} \mathrm{H}_{2} \mathrm{O} \mathrm{m}^{-2} \mathrm{~s}^{-1}\right)$ compared to N0K30 $\left(227 \mathrm{~mol} \mathrm{H}_{2} \mathrm{O}\right.$ $\left.\mathrm{m}^{-2} \mathrm{~s}^{-1}\right)$, which represented higher carbon assimilation and could have directly contributed to active Cond (0.094 mol H $\mathrm{H} \mathrm{m}^{-2} \mathrm{~s}^{-1}$ ) (Figure 2). Meanwhile, plants in NOKO were perhaps experiencing diffusion resistance along the experiments (Chen et al., 2013). This finding suggested N0K30 is highly stimulated stomatal opening and closing. 


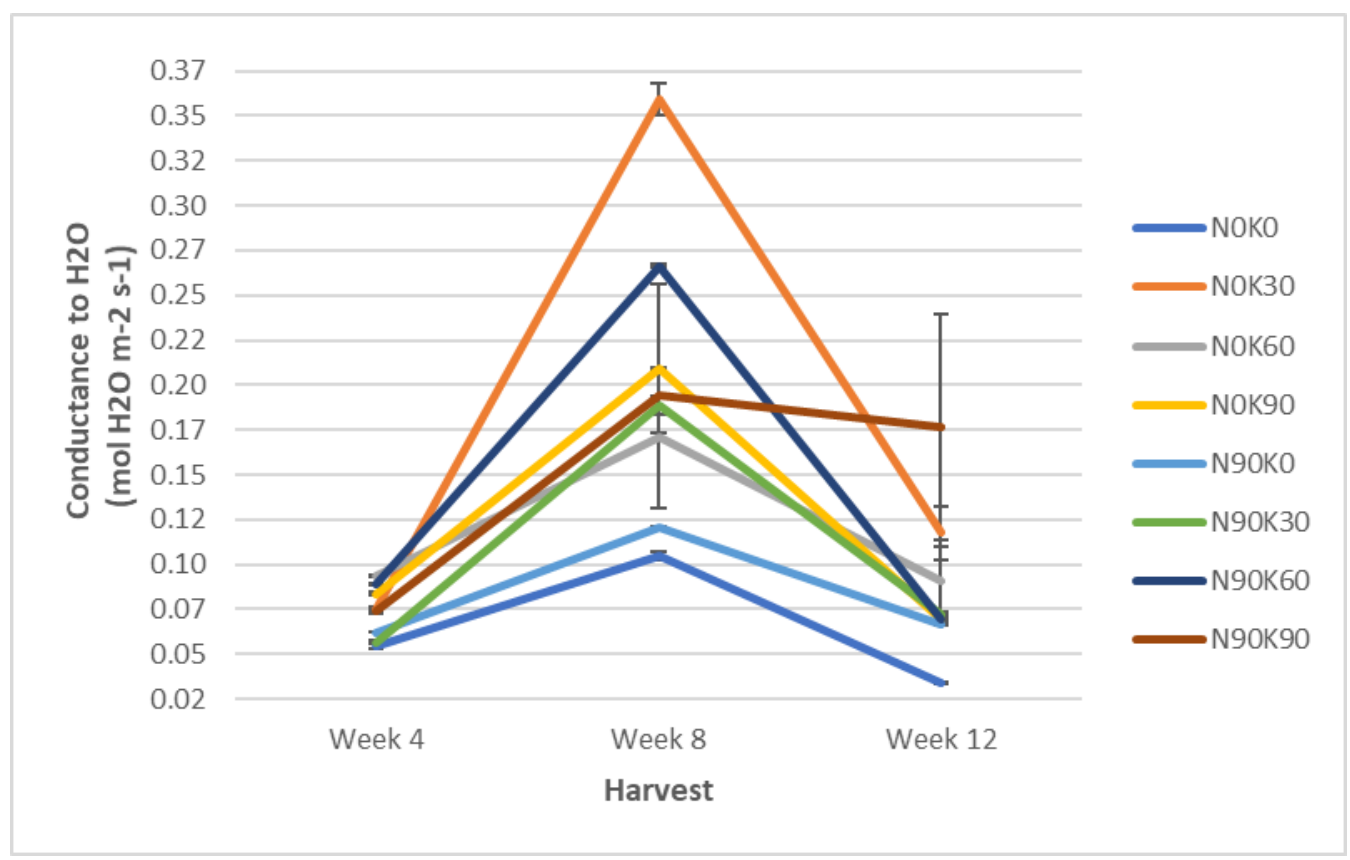

Figure 2. Changes in Cond $\left(\mathrm{mol} \mathrm{H}_{2} \mathrm{O} \mathrm{m} \mathrm{m}^{-2} \mathrm{~s}^{-1}\right)$ as affected by rates of $\mathrm{N}(0$ and $90 \mathrm{~kg} \mathrm{~N} / \mathrm{ha}), \mathrm{K}[0$ (Control), $30,60$ and $90 \mathrm{~kg} \mathrm{~K} / \mathrm{ha}$ ] and $\mathrm{H}$ times (4, 8 and $12 \mathrm{WAT})$. Bars represents standard error of differences between the means. $\mathrm{N}=72$.

\section{Total Chlorophyll Contents}

Generally, TChIC was statistically affected in all treatments and age as indicated by the $\mathrm{H}$ time $(\mathrm{p} \leq 0.0001)$ (Figure 3). At Week 4, the N0K90 treatment recorded significantly ( $p \leq 0.0001$ ) highest value of TChIC compared to other treatments which were not significantly different $(p \geq 0.05)$ to each other with the lowest value recorded in N9OK0. However, as the plant aged to Week 8 and 12, the N90K0 recorded increased TChIC $\left(9.00 \mathrm{\mu g} \mathrm{g}^{-1} \mathrm{FW}\right)(\mathrm{p} \leq 0.0001)$, followed by N90K30 $\left(8.70 \mu \mathrm{g} \mathrm{g}^{-1} \mathrm{FW}\right)$. Meanwhile, other treatments were decreased, NOKO $\left(8.10 \mu \mathrm{g} \mathrm{g}^{-1} \mathrm{FW}\right)$, NOK30 (8.80 $\left.\mathrm{ug} \mathrm{g}^{-1} \mathrm{FW}\right)$, NOK60 (8.60 $\left.\mathrm{gg} \mathrm{g}^{-1} \mathrm{FW}\right)$, N0K90 (7.70 $\left.\mu \mathrm{g} \mathrm{g}{ }^{-1} \mathrm{FW}\right)$, N90K60 (8.70 $\left.\mu \mathrm{g} \mathrm{g}^{-1} \mathrm{FW}\right)$, and N90K90 (4.60 $\left.\mathrm{\mu g} \mathrm{g}^{-1} \mathrm{FW}\right)$. In this experiment, TChIC was highest in N0K90 at Week 4 compared to N90K0 (Figure 3). However, measurements of TChIC are not significantly correlated with Photo at $r=-0.059 ; p \geq 0.05$ by a linear function (Table 1 ). The values are concurrent to Cond rates at Week 4 (Figure 2), where gas exchange rate leaf was low, and increased during Week 8 and subsequently decreased by $8 \%$ at Week 12 . The event was because of pre-adaptation (acclimatisation), adaptation (growth) and post-adaptation (maturing) during plant growth cycle where $\mathrm{N}$ and $\mathrm{K}$ are vital component of plants energy metabolism and of activated intermediates in the photosynthesis following the growth cycle requirement accordingly (Pant et al., 2015). Meanwhile, high $\mathrm{N}$ rate reported significantly decreased chlorophyll content $(\mathrm{p} \leq 0.05)$ (Rahimi et al., 2013), and sufficient rates of K in N0K90 was determined the TChIC highest in the treatment where optimum K rate resulted in a maximum net Photo that could be associated with the highest chlorophyll content and fully open stomata conductance (Chen et al., 2013) (Figures 1, 2 and 3). 


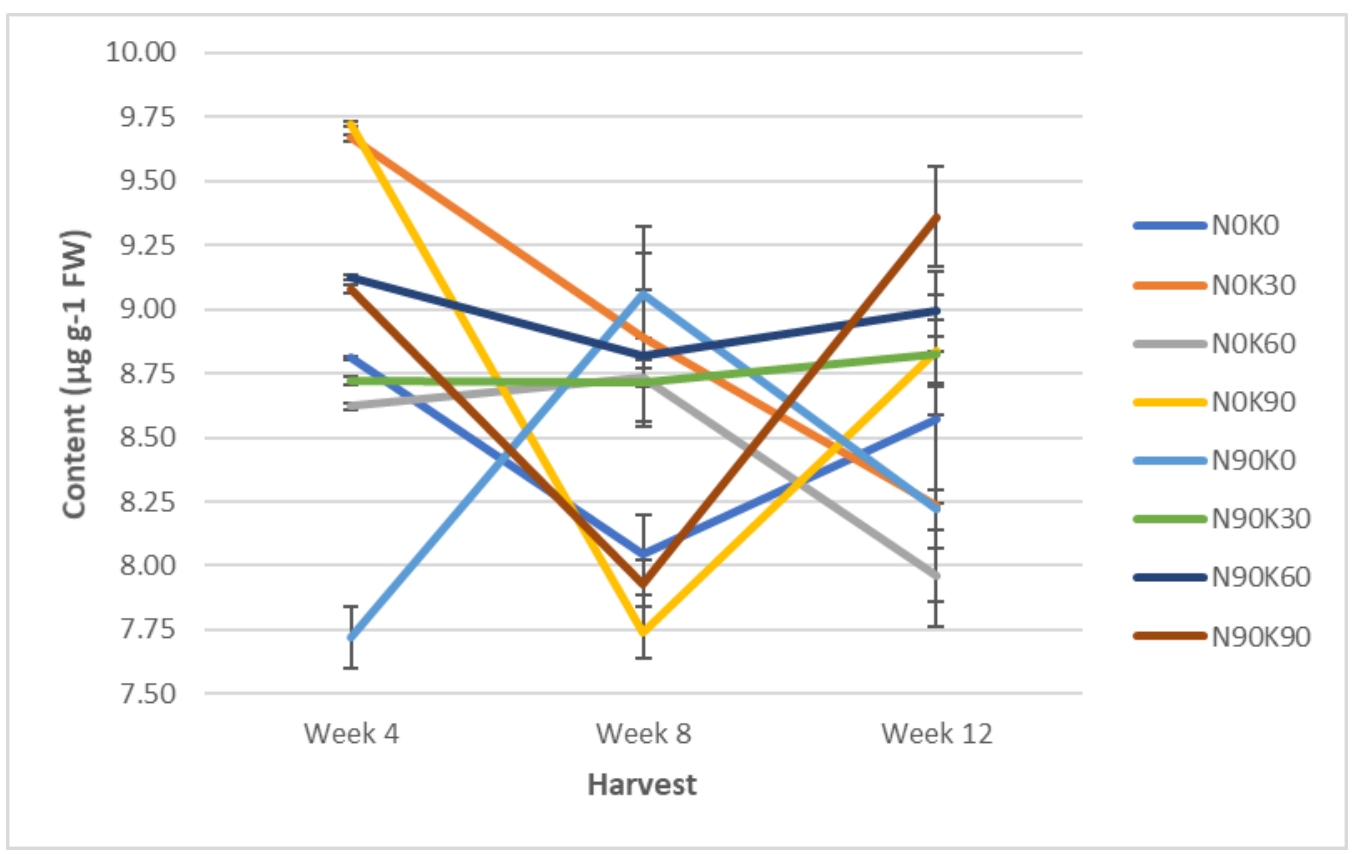

Figure 3. Changes in TChIC ( $\left.\mu \mathrm{g} \mathrm{g}^{-1} \mathrm{FW}\right)$ as affected by rates of $\mathrm{N}(0$ and $90 \mathrm{~kg} \mathrm{~N} / \mathrm{ha}), \mathrm{K}$ [0 (Control), 30, 60 and $90 \mathrm{~kg} \mathrm{~K} / \mathrm{ha}$ ] and $\mathrm{H}$ times (4, 8 and 12 WAT). Bars represents standard error of differences between the means. $\mathrm{N}=72$.

\section{Total Carbohydrates Content}

Generally, TCC was statistically affected in all treatments at different plant age as represented by the $\mathrm{H}$ time ( $\mathrm{p} \leq 0.001$ ) (Figure 4). The N90KO treatment has increased tremendously TCC followed by N0K60, N90K60, N0K90, N90K30, N90K90, NOK30, and N0K0 when applied during early growth at Week 4. As the growth progressed to Weeks 12, N90K0 continued to increase TCC from 105 to $250 \mathrm{mg}$ GE/g DW compared to NOKO, which value did not continue to surpass all other treatments; instead the value was almost like NOK30, N0K90, N90K30, and N90K90 (Figure 4). Nitrogen is an essential element constituent of plant compounds that determine the quality of plant organic material (Macadam, Volenec, \& Nelson, 1989). Meanwhile, $\mathrm{K}$ is involved in the activities of over 60 types of plant enzymes including metabolism of $\mathrm{N}$ and carbohydrates (Chen et al., 2013). In this experiment, TCC was increased significantly with continuing $\mathrm{H}$ time and increasing $\mathrm{N}$ rate $(\mathrm{p} \leq 0.05)$ (Figure 4). Measurements of TCC are significantly correlated with TPrC at $r=-0.293 ; p \leq 0.05$. However, not significantly correlated with Photo, TLiC, TPC and TFC at $r=-0.226 ; p \geq 0.05, r=-0.078 ; p \geq 0.05, r=-0.208 ; p \geq 0.05$ and $r=-0.192 ; p \geq 0.05$, respectively by a linear function (Table 1). The event was because of high $\mathrm{N}$ rate would increase sugar content and promote the accumulation of soluble sugars of plants (Aminifard et al., 2012). Meanwhile, when TCC decreased, the TPrc will increased (Figure 5), decreased photosynthetic capacity (Figure 1), and increased respiration rate (Figure 2) (Baby et al., 2017). 


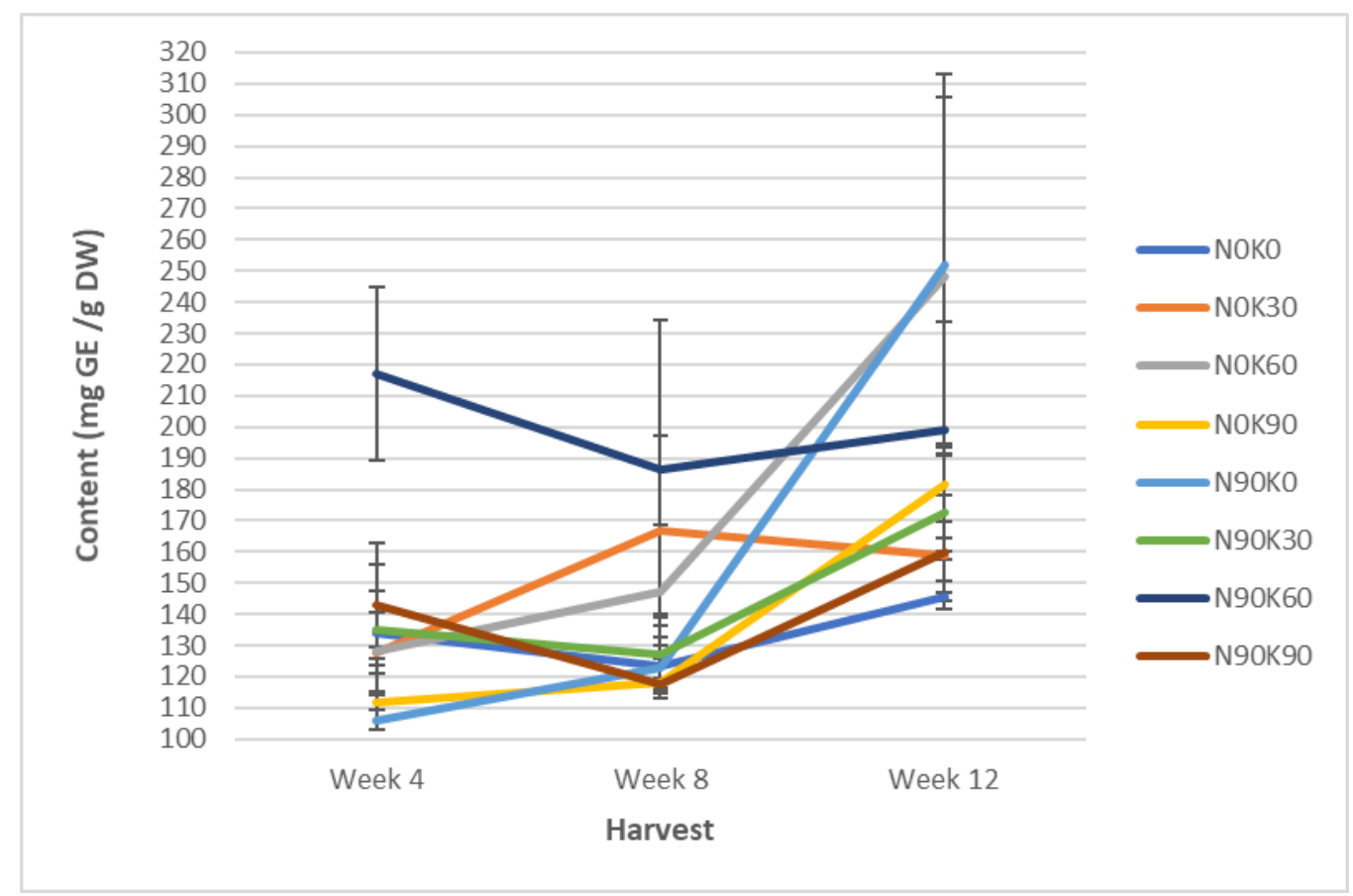

Figure 4. Changes in TCC (mg GE/g DW) as affected by rates of $\mathrm{N}(0$ and $90 \mathrm{~kg} \mathrm{~N} / \mathrm{ha}), \mathrm{K}$ [0 (Control), 30,60 and $90 \mathrm{~kg} \mathrm{~K} / \mathrm{ha}$ ] and $\mathrm{H}$ times (4, 8 and $12 \mathrm{WAT}$ ). Bars represents standard error of differences between the means. $\mathrm{N}=72$. The calibration curves for TCC markers (glucose) were linear over the range of 0.0 to $100.0 \mathrm{mg} / \mathrm{mL}$. The coefficient of determination $\left(R^{2}\right)$ was greater than 0.995 for all standard curves.

\section{Total Protein Content}

Generally, TPrC was statistically affected in all treatments and $\mathrm{H}$ time ( $\mathrm{p} \leq 0.01)$ (Figure 5). At early growth stage (Week 4), the N90K0 treatment recorded significantly the highest $(p \leq 0.0001)$ TPrC value $(11 \mathrm{mg}$ BSAE/g DW) followed by NOK0 (10 mg BSAE/g DW), N90K90 (9.80 mg BSAE/g DW), N0K30 (9.50 mg BSAE/g DW), N0K60 (7.50 mg BSAE/g DW), N90K30 (7 mg BSAE/g DW), N0K90 (6 mg BSAE/g DW), and N90K60 (3.50 mg BSAE/g DW). However, during Week 12, TPrC has decreased in N90K0, which showed lower and almost similar with NOK30 value. Meanwhile, TPrC has increased tremendously in $\mathrm{N} 90 \mathrm{~K} 30$ and N90K90 with increasing $\mathrm{H}$ time from Week 8 to 12. In this experiment, TPrC was highest in $\mathrm{N} 90 \mathrm{~K} 30$ and N90K90, and lowest in N90K60 with continuing $\mathrm{H}$ time (Figure 5). Measurements of TPrC are significantly correlated with TCC at $r=-0.293 ; p \leq 0.05$. However, not correlated with Photo, TLiC, TPC and TFC at $r=-0.088 ; p \geq 0.05, r=-0.296 ; p \geq 0.05, r=0.024 ; p \geq 0.05$ and $r=0.086 ; p \geq 0.05$, respectively by a linear function (Table 1). The event was because of plants protein contents in each treatment are affected by $\mathrm{N}$ rates. Meanwhile, $\mathrm{K}$ may influence the metabolic processes, such as turgor driven movements, osmoregulation, control of membrane polarization and involved with enzyme activation which affects the protein and protein-related compound (Mohamad Bukhori et al., 2015). Meanwhile, in N90K30 and N90K90 probably sufficient $\mathrm{N}$ and $\mathrm{K}$ rates has led to effective photosynthesis rates and trade-off with carbohydrate synthesis by increasing the proportion of soluble protein (Anulika et al., 2016). In this experiment, high $\mathrm{N}$ and $\mathrm{K}$ rate exhibited higher TPrC could be related to value recorded in TChIC (Figure 3 ) and TCC (Figure 4) presented by N90K30 and N90K90. Plants that were supplied with enough K rate showed a greater capacity for nitrate assimilation. And $\mathrm{N}$ is crucial for plants to perform the routine and fundamental cellular activities. This include photosynthetic products which provide the energy and Cskeletons for amino acid synthesis during protein biosynthesis (Chen et al., 2013). 


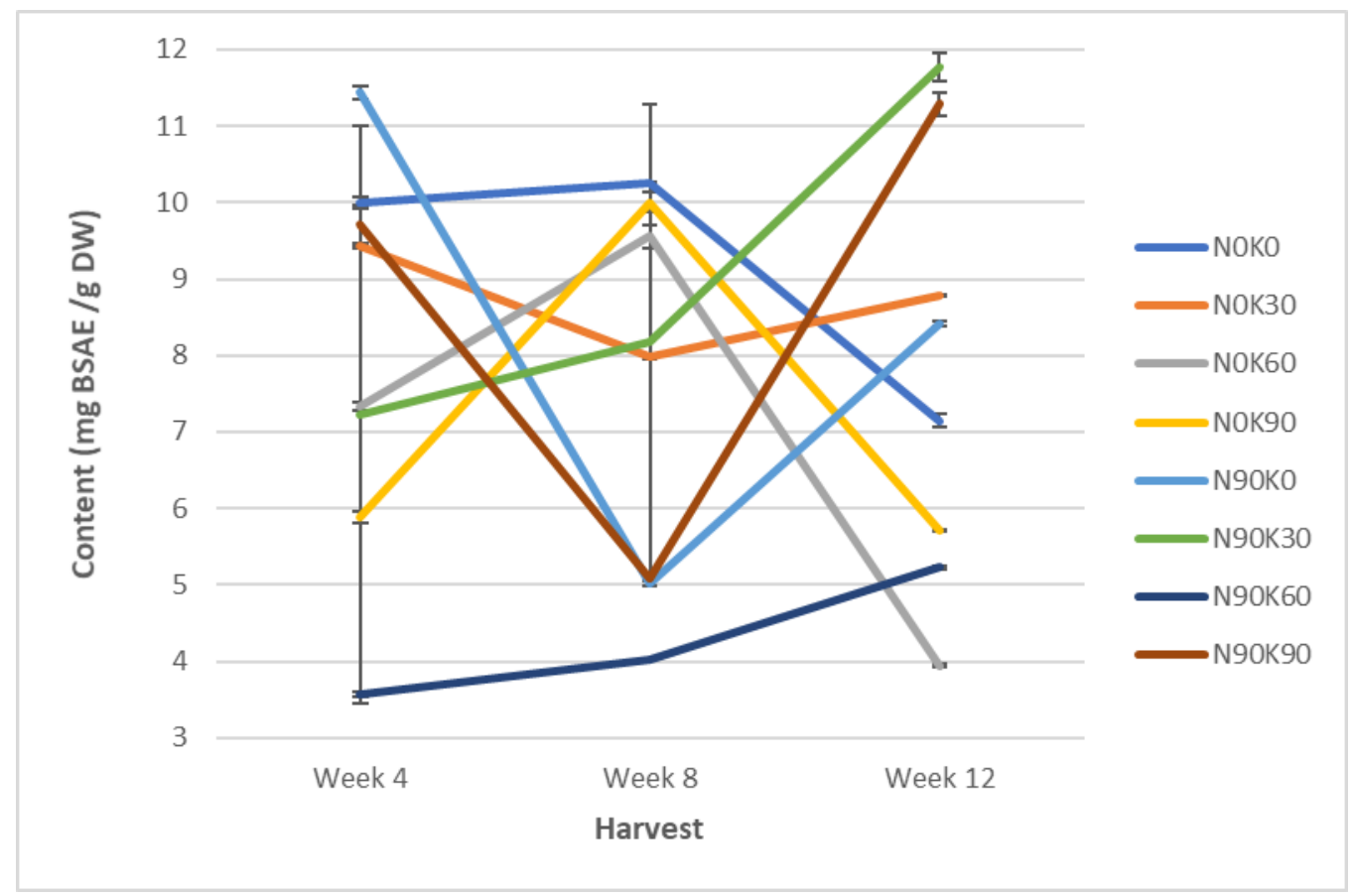

Figure 5. Changes in TPrC (mg BSAE/g DW) as affected by rates of $\mathrm{N}$ ( 0 and $90 \mathrm{~kg} \mathrm{~N} / \mathrm{ha}), \mathrm{K}$ [0 (Control), 30,60 and $90 \mathrm{~kg} \mathrm{~K} / \mathrm{ha}$ ] and $\mathrm{H}$ times (4, 8 and $12 \mathrm{WAT}$ ). Bars represents standard error of differences between the means. $\mathrm{N}=72$. The calibration curves for TPrC markers (bovine serum albumin) were linear over the range of 0.0 to $1.0 \mathrm{mg} / \mathrm{mL}$. The coefficient of determination $\left(R^{2}\right)$ were greater than 0.990 for all standard curves.

\section{Total Lipid Content}

Generally, TLiC was statistically affected in all treatments and $\mathrm{H}$ time $(p \leq 0.0001)$ (Figure 6). At early growth, all treatments have started to influence the TLiC. With increase in age from Week 8 to Week 12, NOK30, N0K60, N90K0, N90K30, and N90K60 have increased the value of TLiC tremendously ( $p \leq 0.05)$ from the lowest value at $10 \mathrm{mg} / \mathrm{g}$ DW to $63 \mathrm{mg} / \mathrm{g}$ DW. Meanwhile, N90K90 treatment which recorded highest value at Week 8 (70 mg/g DW) compared to all treatments, upon reaching Week 12 has recorded significantly lower $(p \leq 0.05)$ TLiC than that recorded by N0K30 and N90K0 but equal to N0K60 and N90K30 and higher than TLiC value in N0K90 and N90K60 (Figure 6). Measurements of TLiC are significantly correlated with Photo at $r=0.286 ; p \leq 0.05$. However, not significantly correlated with TCC, TPrC, TPC and TFC at $r=-0.078 ; p \geq 0.05, r=-0.296 ; p \geq 0.05, r=0.046 ; p \geq 0.05$ and $r=0.042 ; p \geq 0.05$, respectively by a linear function (Table 1 ). In this experiment, TLiC has fluctuate with continuing $\mathrm{H}$ time and rising $\mathrm{N}$ and $\mathrm{K}$ rates. The event was because of metabolically, lipid synthesis may be related to development of intracellular membranous compartmentation and the availability of intracellular (nonplasmic and periplasmic) spaces as plant ages (Ora \& Anekwe, 2013). Since vacuoles are intracellular spaces function as accumulation sites for plant metabolites, therefore, vacuolar membranes might play a pivotal role in compartmentalized acquisition, sequestration and retention of metabolites, including lipids (Mishra et al., 2006). On the other hands, TLiC has increased during leaf expansion in order to attain optimum level at full maturity and substantial decline in senescing tissue of old plants (Mishra et al., 2006). At the same time, $\mathrm{K}$ has influenced the metabolism of $\mathrm{N}$, carbohydrates and protein, and the synthesis of lipid. This is because, $\mathrm{K}$ may exhibit changes in $\mathrm{N}: \mathrm{K}$ ratio instead of $\mathrm{N}: \mathrm{P}$ and/or in the $\mathrm{N}$ fractions proportions during lipid synthesis in the plant (Chrysargyris et al., 2017). 


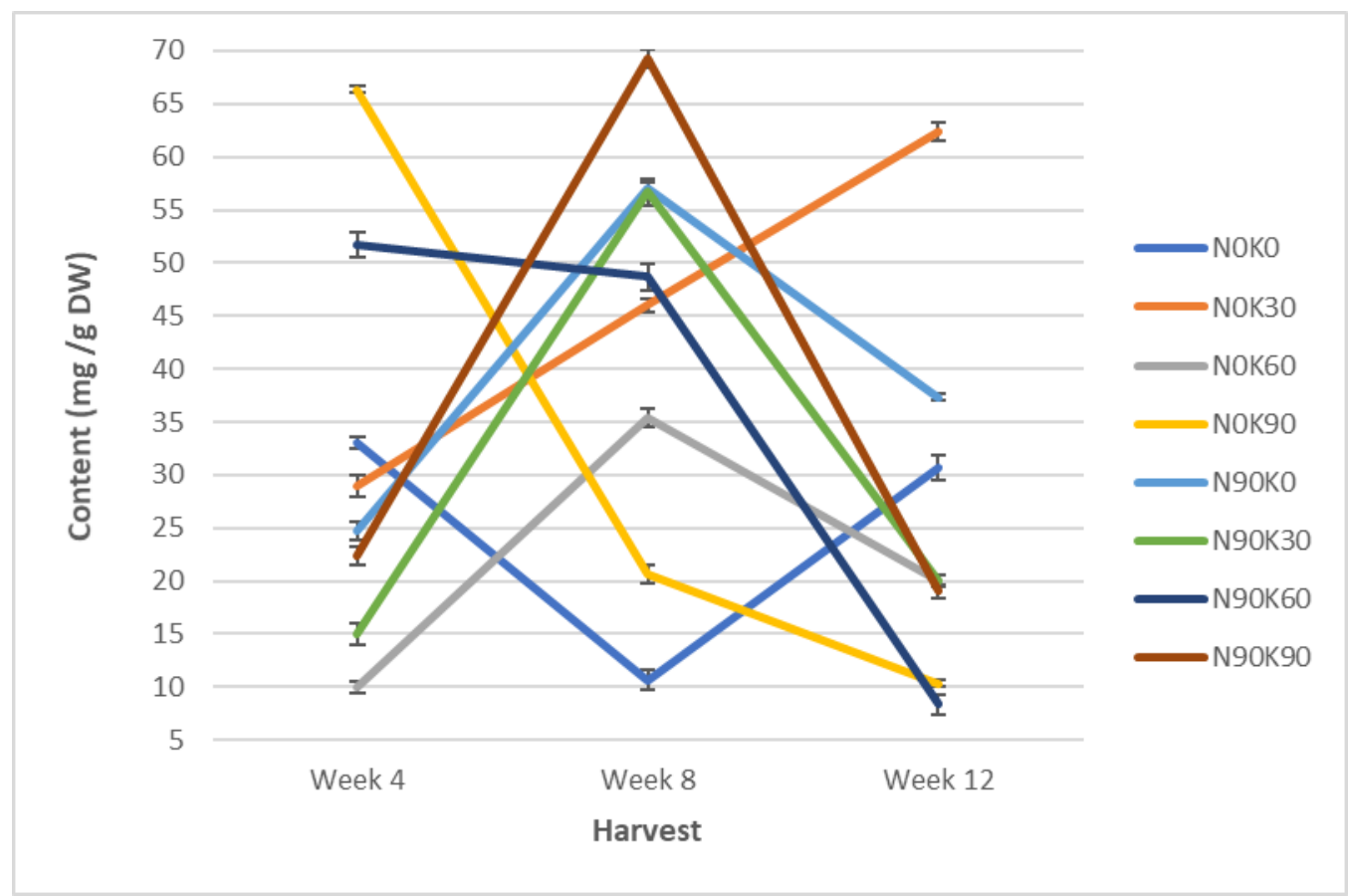

Figure 6. Changes in TLiC (mg/g DW) as affected by rates of $\mathrm{N}(0$ and $90 \mathrm{~kg} \mathrm{~N} / \mathrm{ha}), \mathrm{K}$ [0 (Control), 30, 60 and $90 \mathrm{~kg} \mathrm{~K} / \mathrm{ha}$ ] and $\mathrm{H}$ times (4, 8 and $12 \mathrm{WAT}$ ). Bars represents standard error of differences between the means. $\mathrm{N}=72$.

\section{Total Phenolic Content}

Generally, TPC was statistically affected in all treatments at different $\mathrm{H}$ time ( $\mathrm{p} \leq 0.0001)$ (Figure 7). At Week 4, TPC value was significantly decreased ( $p \leq 0.0001)$ with different $\mathrm{N}$ and $\mathrm{K}$ treatment in descending manner NOKO (104 mg CAE/g DW) > N0K30 (100 mg CAE/g DW) > N0K90 (88 mg CAE/g $\mathrm{DW})>\mathrm{N} 90 \mathrm{~K} 30(80 \mathrm{mg} \mathrm{CAE} / \mathrm{g} \mathrm{DW})>\mathrm{N} 0 \mathrm{~K} 60(78 \mathrm{mg} \mathrm{CAE} / \mathrm{g} \mathrm{DW})>\mathrm{N} 90 \mathrm{KO}(70 \mathrm{mg} \mathrm{CAE} / \mathrm{g} \mathrm{DW})>\mathrm{N} 90 \mathrm{~K} 60$ $(60 \mathrm{mg} \mathrm{CAE} / \mathrm{g} \mathrm{DW})>\mathrm{N} 90 \mathrm{~K} 90$ (52 $\mathrm{mg} \mathrm{CAE} / \mathrm{g} \mathrm{DW})$. As the plant aged indicated by $\mathrm{H}$ time from Week 4 to Week 12, TPC has increased $(p \leq 0.05)$ in N0K60 followed by N90K60 and N90K90 (Figure 7). Measurements of TPC are significantly correlated with TFC at $r=0.573 ; p \leq 0.0001$. However, not significantly correlated with Photo, TCC, TPrC and TLiC at $r=0.225 ; p \geq 0.05, r=-0.208 ; p \geq 0.05, r=0.024$; $p \geq 0.05$ and $r=0.046 ; p \geq 0.05$, respectively by a linear function (Table 1 ). The event was due to $\mathrm{N}$ supply rate. Low $\mathrm{N}$ treatment, resulted in an up-regulation of the phenolic synthesis, as demonstrated by an increase in the TPC. The amplitude of the increase in phenolic content did not depend on the Photo to which the plant was subjected, which indicates that the plants did not acclimate to low Photo (5 to $6 \mu \mathrm{mol}$ $\mathrm{CO}_{2} \mathrm{~m}^{-2} \mathrm{~s}^{-1}$ ) (Figure 1) (Larbat et al., 2012). However, successive $\mathrm{K}$ supply resulted in additive increases in phenolic content. 


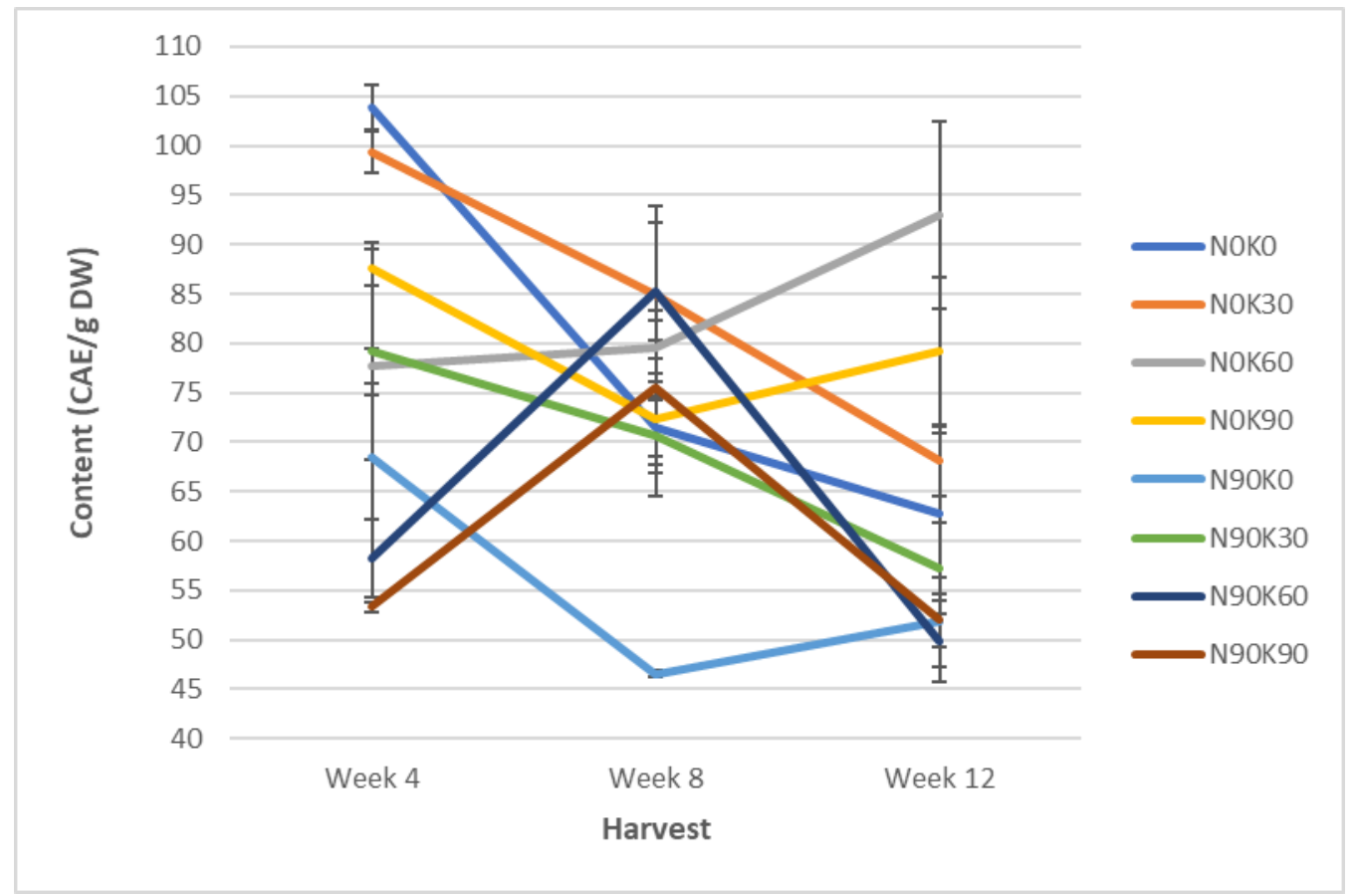

Figure 7. Changes in TPC (mg CAE/g DW) as affected by rates of $\mathrm{N}(0$ and $90 \mathrm{~kg} \mathrm{~N} / \mathrm{ha}), \mathrm{K}[0$ (Control), 30,60 and $90 \mathrm{~kg} \mathrm{~K} / \mathrm{ha}$ ] and $\mathrm{H}$ times (4, 8 and $12 \mathrm{WAT}$ ). Bars represents standard error of differences between the means. $\mathrm{N}=72$. The calibration curves for TPC markers (caffeic acid) were linear over the range of 0.1 to $2.0 \mathrm{mg} / \mathrm{mL}$. The coefficient of determination $\left(R^{2}\right)$ was greater than 0.994 for all standard curves.

\section{Quantification of Phenolics}

\section{Thin Layer Chromatography}

Qualitative analysis of methanol extract using TLC was performed using a mixture of toluene: ethyl acetate: formic acid (5:4:1 v/v) used as the mobile phase (Sasidharan et al., 2011) yielded a good resolution of caffeic acid with bands at $R_{f}=0.66$ (Figure 8). Caffeic acid were identified as phytochemical marker in phenolic compounds analysis and quantified at visible light and visible wavelength of 254 and $366 \mathrm{~nm}$ before derivatisation (Figure 8). The results revealed that methanol extract at $1 \mathrm{~g} / 10 \mathrm{~mL}$ of $100 \%$ methanol contained caffeic acid in accordance to TPC analysis, where highest in N0K30 at Week 4 (100 $\mathrm{mg} \mathrm{CAE} / \mathrm{g} \mathrm{DW}$ ), and lowest in N90K60 treatments at Week 12 (50 mg CAE/g DW) (Figure 7). This TLC procedure can be used as a fast screening method for $G$. procumbens leaf samples and herbal formulations. 

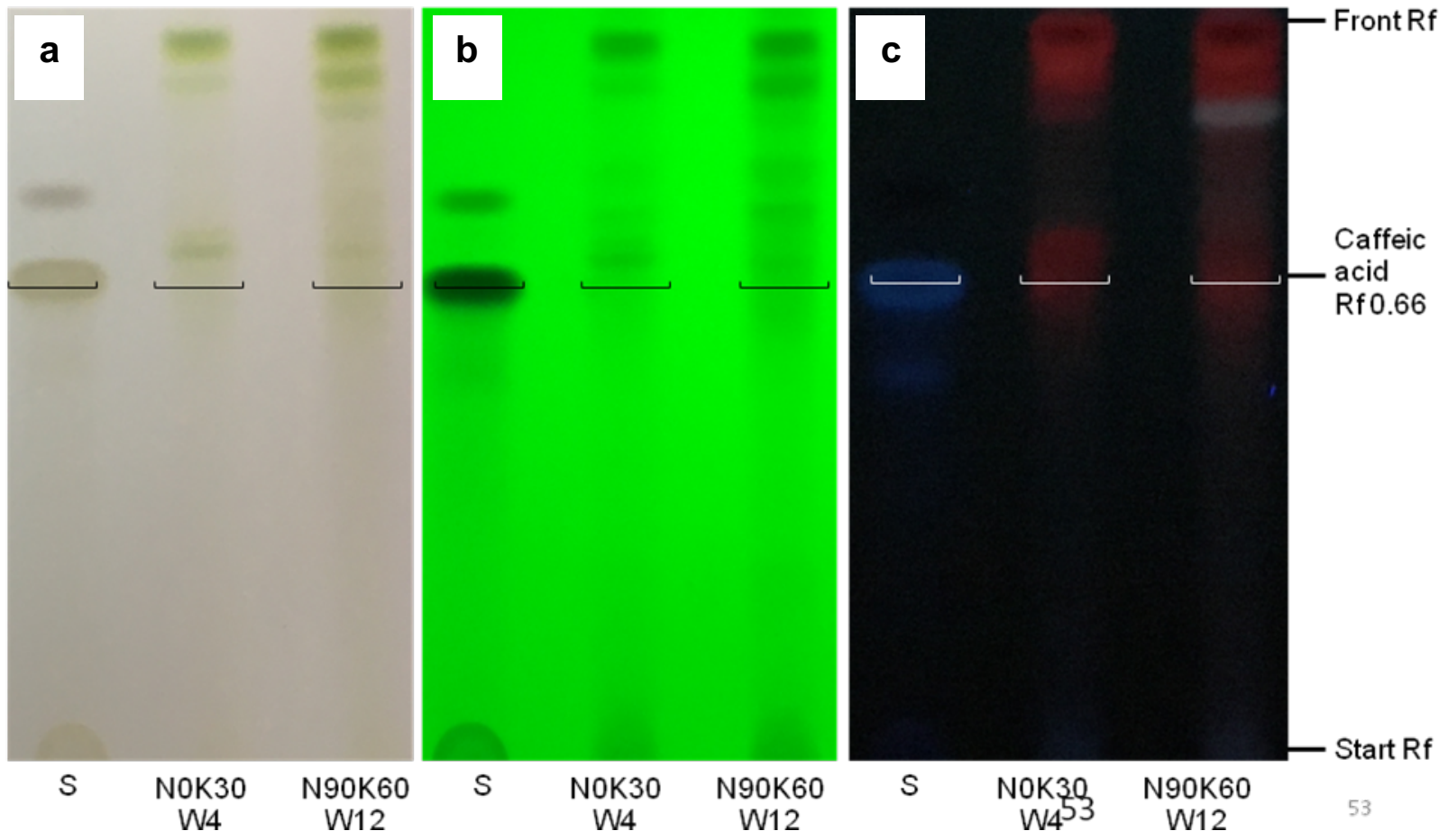

Figure 8. Thin layer chromatography developed-profiles of caffeic acid (S) of methanolic extract of dried leaves powder for N0K30 treatment Week 4 and N90K60 treatment Week 12 observed under various wavelength (visible light, a; 254 $\mathrm{nm}, \mathrm{b}$; and $366 \mathrm{~nm}, \mathrm{c}$ ) before derivatization.

\section{High-Performance Liquid Chromatography}

Quantitative analysis of methanol extract using HPLC was performed using a mixture of $0.1 \%$ of $85 \%$ orthophosphoric acid: acetonitrile (90.5:9.5, v/v isocratically) (Kaewseejan \& Siriamornpun, 2015) used as the eluent yielded a good peak of caffeic acid at $t_{r}=6.6$ to $6.7 \mathrm{~min}, 327 \mathrm{~nm}$ (Figure 9). The results revealed that methanol extract at $1 \mathrm{~g} / 10 \mathrm{~mL}$ of $100 \%$ methanol contained caffeic acid as phytochemical marker in accordance to TPC analysis, where highest in N0K30 at Week 4 (100 mg CAE/g DW), peak 4, $t_{r}=6.716 \mathrm{~min}, 39.03 \%$ Area, and lowest in N90K0 treatments at Week 12 (50 mg CAE/g DW), peak 4, $t_{r}=6.649 \mathrm{~min}, 19.61 \%$ Area) (Figures 7 and 9). This HPLC procedure can be used as a fast screening method for $G$. procumbens leaf samples and herbal formulations. 

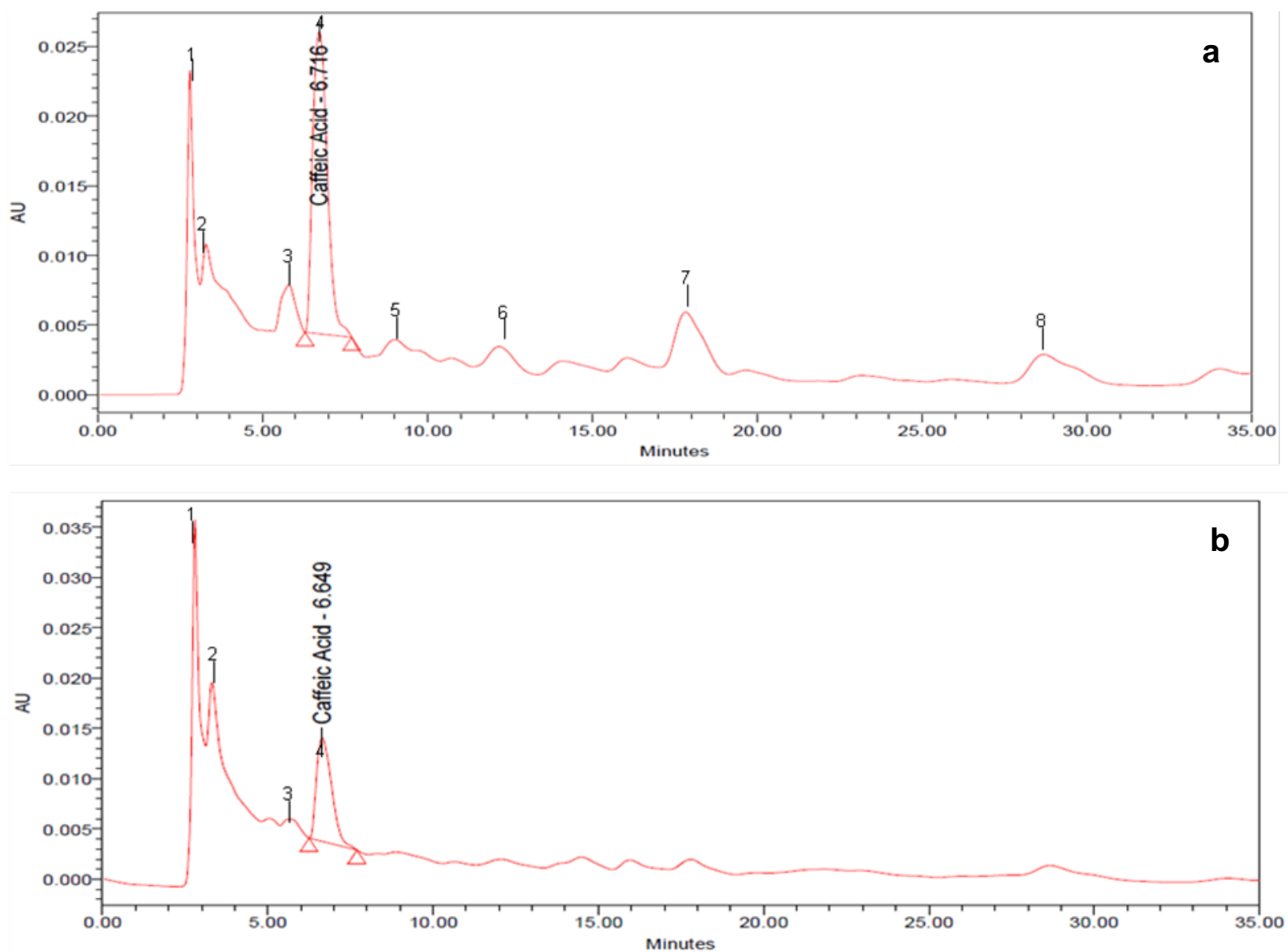

Figure 9. High-performance liquid chromatogram developed-profiles of caffeic acid standard solution $(1.0 \mathrm{mg} / \mathrm{mL})$ at $t_{r}=6.6-6.7 \mathrm{~min}$ of methanolic extract of dried leaves powder for N0K30 treatment Week 4 (a) and N90K60 treatment Week 12 (b) observed under $327 \mathrm{~nm}$ derivatization. The calibration curves for caffeic acid were linear over the range of 0.05 to $0.17 \mathrm{mg} / \mathrm{mL}$. The coefficient of determination $\left(R^{2}\right)$ was greater than 0.999 for all standard curves.

\section{Total Flavonoid Content}

Generally, TFC was statistically affected in all treatments at different $\mathrm{H}$ time ( $\mathrm{p} \leq 0.0001)$ (Figure 10). At Week 4, TFC value was significantly decreased ( $\mathrm{p} \leq 0.0001)$ with different $\mathrm{N}$ and $\mathrm{K}$ treatment in descending manner N0K30 $(72 \mathrm{mg} \mathrm{KE} / \mathrm{g} \mathrm{DW})>$ NOKO $(71 \mathrm{mg} \mathrm{KE} / \mathrm{g} \mathrm{DW})>$ N0K90 $(63 \mathrm{mg} \mathrm{KE} / \mathrm{g} \mathrm{DW})>$ N90K30 (60 mg KE/g DW) > N90K0 (55 mg KE/g DW) > N0K60 (47 mg KE/g DW) > N90K60 (36 mg $\mathrm{KE} / \mathrm{g} \mathrm{DW})>\mathrm{N} 90 \mathrm{~K} 90(25 \mathrm{mg} \mathrm{KE} / \mathrm{g} \mathrm{DW})$. As the plant aged indicated by $\mathrm{H}$ time from Week 4 to Week 12, TFC has increased $(p \leq 0.05)$ in N90K60 and N90K90, however, decreased in other treatments (Figure 10). Measurements of TFC are significantly correlated with TPC at $r=0.573 ; p \leq 0.0001$. However, not significantly correlated with Photo, TCC, TPrC and TLiC at $r=0.079 ; p \geq 0.05, r=-0.192 ; p \geq 0.05, r=0.086$; $p \geq 0.05$ and $r=0.142 ; p \geq 0.05$, respectively by a linear function (Table 1). The event was because of $N$ availability has implicated phytochemical response in plants (Galieni et al., 2015), where N deficiency induces the content of flavonoids and flavonols (Pal et al., 2015). High N supply (N90 treatment) increases the content of nitrogenous compounds, such as free amino acids (protein) (Figure 5), which however, reduce the secondary metabolites content such as flavonoid (Larbat et al., 2012). Meanwhile, low $\mathrm{K}$ rates has influenced enzyme activation metabolism which affects the protein and protein-related compound production. This compounds are precursors of secondary metabolites formation (flavonoids) (Ozdal et al., 2013). 


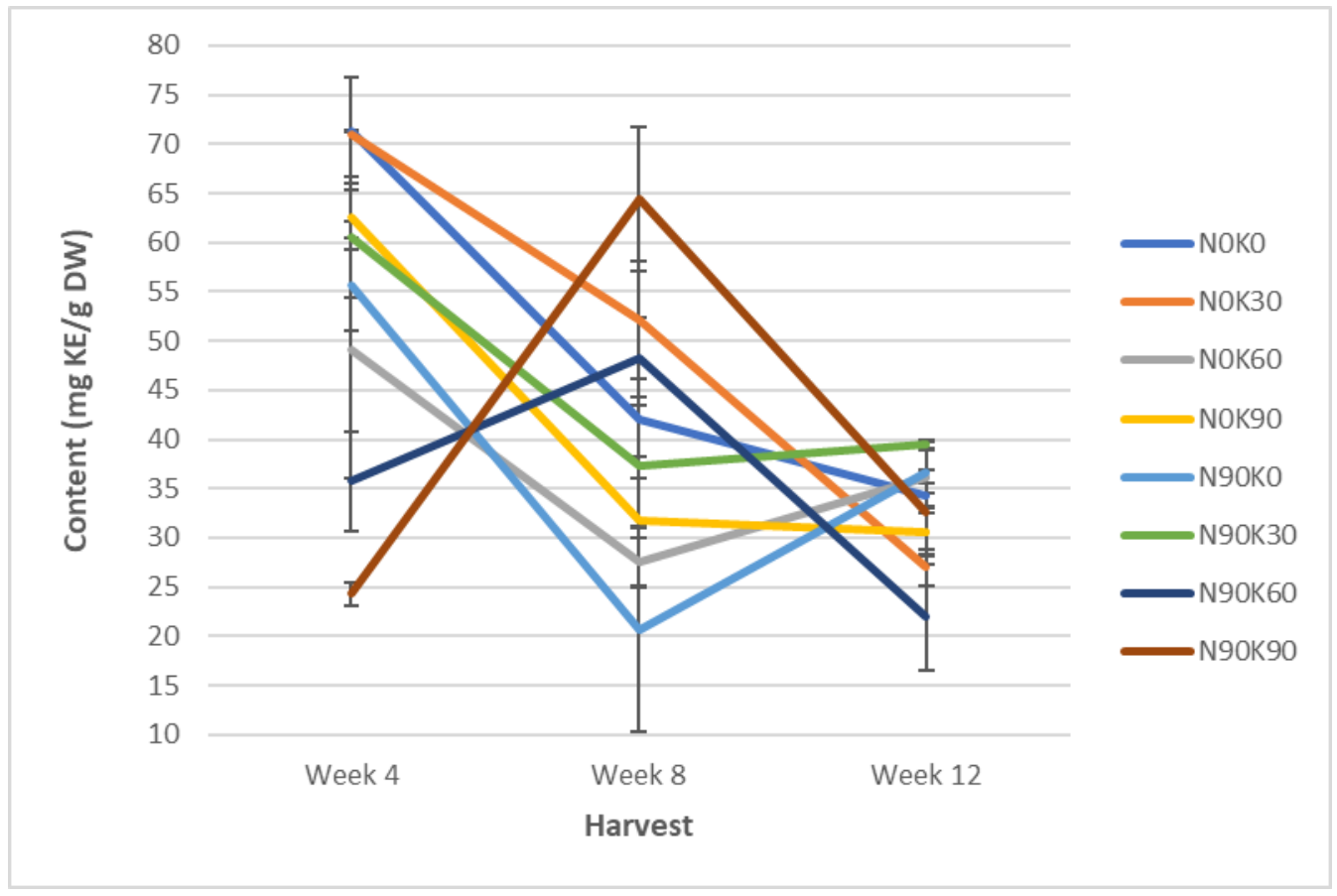

Figure 10. Changes in TFC (mg KE/g DW) as affected by rates of $\mathrm{N}(0$ and $90 \mathrm{~kg} \mathrm{~N} / \mathrm{ha}), \mathrm{K}[0$ (Control), 30,60 and $90 \mathrm{~kg} \mathrm{~K} / \mathrm{ha}$ ] and $\mathrm{H}$ times (4, 8 and $12 \mathrm{WAT}$ ). Bars represents standard error of differences between the means. $\mathrm{N}=72$. The calibration curves for TFC markers (kaempferol) were linear over the range of 0.04 to $1.80 \mathrm{mg} / \mathrm{mL}$. The coefficient of determination $\left(R^{2}\right)$ was greater than 0.993 for all standard curves.

\section{Quantification of Flavonoids}

\section{Thin Layer Chromatography}

Qualitative analysis of methanol extract using TLC was performed using a mixture of toluene: ethyl acetate: formic acid (5:4:1 v/v) used as the mobile phase (Sasidharan et al., 2011) yielded a good resolution of kaempferol with bands at $R_{f}=0.71$ (Figure 11). Kaempferol were identified as phytochemical marker in flavonoid compounds analysis and quantified at visible light and visible wavelength of 254 and $366 \mathrm{~nm}$ before derivatisation (Figure 11). The results revealed that methanol extract at $1 \mathrm{~g} / 10 \mathrm{~mL}$ of $100 \%$ methanol contained kaempferol in accordance to TFC analysis, where highest in N0K30 treatments at Week 4 (72 mg KE/g DW), and lowest in N90K60 at Week 12 (36 mg KE/g DW) (Figure 10). This TLC procedure can be used as a fast screening method for $G$. procumbens leaf samples and herbal formulations. 


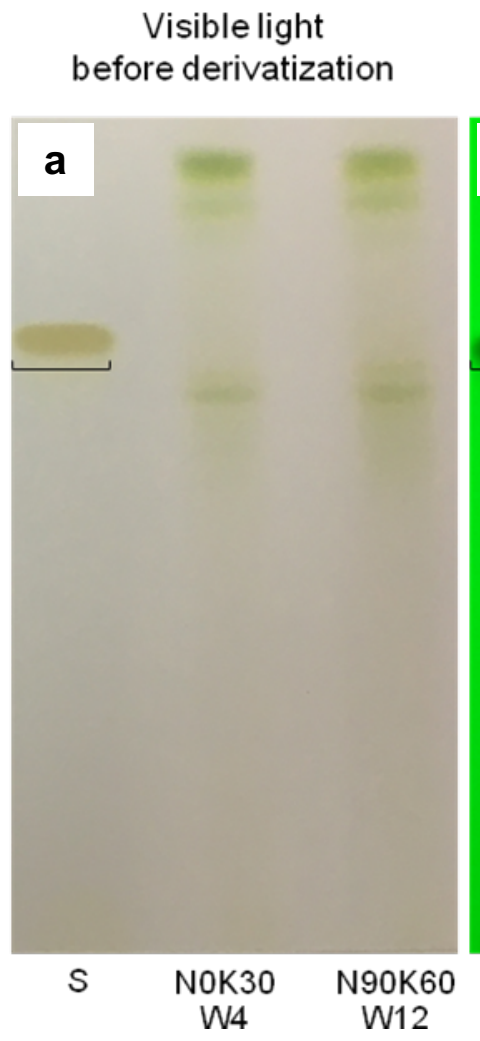

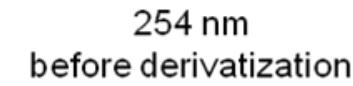
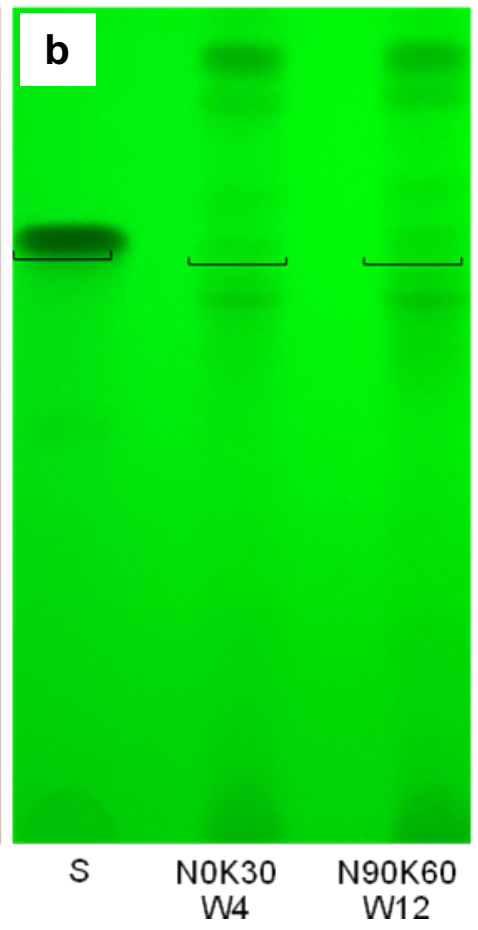

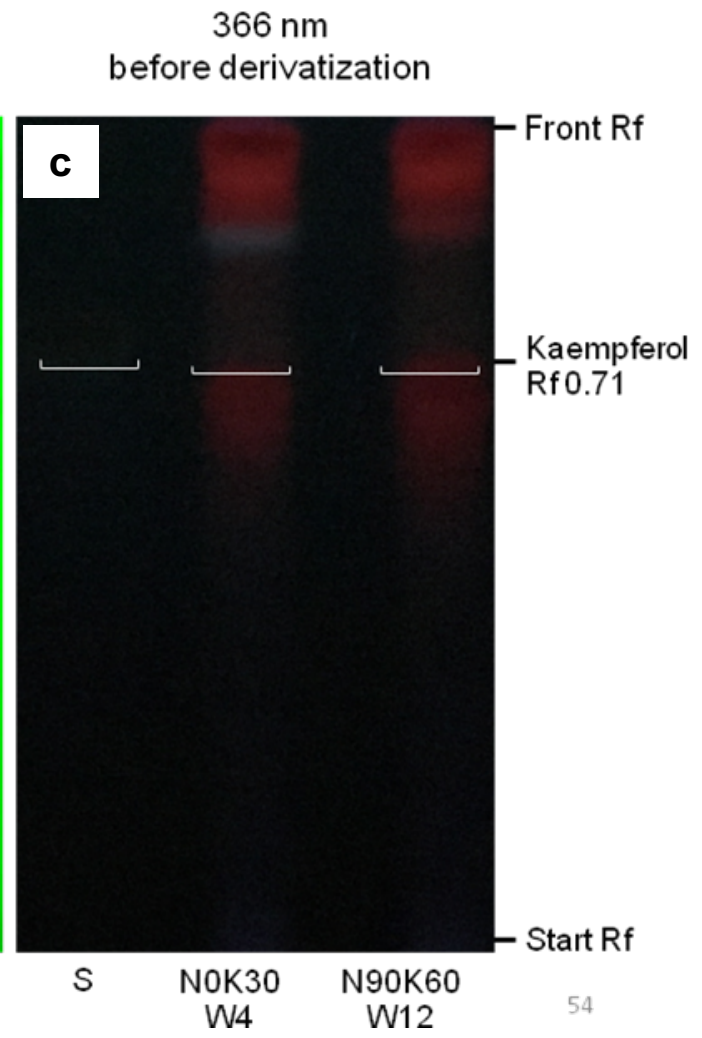

$366 \mathrm{~nm}$

Figure 11. Thin layer chromatography developed-profiles of kaempferol (S) of methanolic extract of dried leaves powder for N0K30 treatment Week 4 and N90K60 Week 12 observed under various wavelength (visible light, a; 254 nm, b; and $366 \mathrm{~nm}, \mathrm{c})$ before derivatization.

\section{High-Performance Liquid Chromatography}

Quantitative analysis of methanol extract using HPLC was performed using a mixture of $0.03 \mathrm{M}$ of $85 \%$ orthophosphoric acid: methanol (60:40, v/v isocratically) (Olszewska, 2007; Yi et al., 2016; Yu et al., 2010) used as the eluent yielded a good peak of kaempferol at $t_{t}=11.0 \mathrm{~min}, 250$ to $360 \mathrm{~nm}$ (Figure 12). The results revealed that methanol extract at $1 \mathrm{~g} / 10 \mathrm{~mL}$ of $100 \%$ methanol contained kaempferol as phytochemical marker in accordance to TFC analysis, where highest in NOK30 treatments at Week 4, peak 6, $t_{i}=11.067 \mathrm{~min}, 39.03 \%$ Area, and lowest in N90K60 at Week 12, peak 2, $t_{r}=11.090 \mathrm{~min}, 16.30 \%$ Area (Figures 10 and 12). This HPLC procedure can be used as a fast screening method for $G$. procumbens leaf samples and herbal formulations. 

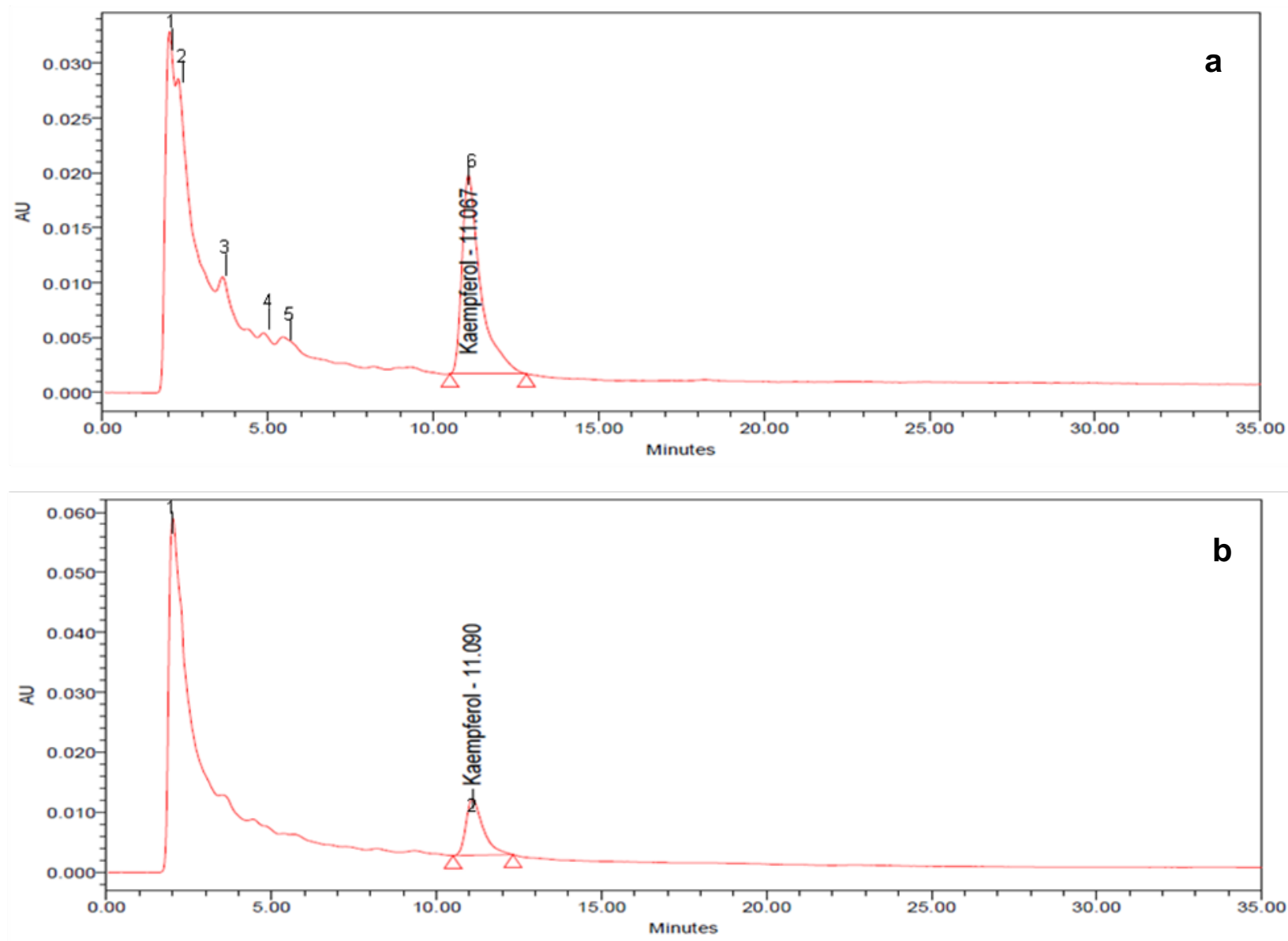

Figure 12. High-performance liquid chromatogram developed-profiles of kaempferol standard solution $(1.0 \mathrm{mg} / \mathrm{mL})$ at $t_{r}=11.0 \mathrm{~min}$ of methanolic extract of dried leaves powder for N0K30 treatment Week 4 (a) and N90K60 treatment Week 12 (b) observed under 250 to $360 \mathrm{~nm}$ derivatization. The calibration curves for kaempferol were linear over the range of 0.2 to $0.6 \mathrm{mg} / \mathrm{mL}$. The coefficient of determination $\left(R^{2}\right)$ were greater than 0.999 for all standard curves. 
Table 1. Correlation of Physiology and Phytochemical Assay.

\begin{tabular}{|c|c|c|c|c|c|c|c|c|c|}
\hline & $\mathrm{H}$ & Photo & Cond & TChIC & TCC & TPrC & TLiC & TPC & TFC \\
\hline$I$ & 1.000 & & & & & & & & \\
\hline $\begin{array}{l}\frac{0}{0} \\
\frac{0}{\alpha}\end{array}$ & $-0.258^{*}$ & 1.000 & & & & & & & \\
\hline $\begin{array}{l}\overline{0} \\
\text { Oे } \\
\end{array}$ & $0.068^{\mathrm{ns}}$ & $0.600^{* * * *}$ & 1.000 & & & & & & \\
\hline$\frac{\frac{U}{\tau}}{\frac{V}{U}}$ & $-0.210^{\mathrm{ns}}$ & $-0.059^{n s}$ & & 1.000 & & & & & \\
\hline U & $0.396^{* * *}$ & $-0.226^{n s}$ & & $-0.048^{\text {ns }}$ & 1.000 & & & & \\
\hline $\begin{array}{l}\text { OL } \\
\text { م }\end{array}$ & $-0.041^{\mathrm{ns}}$ & $-0.088^{\text {ns }}$ & & $-0.108^{\text {ns }}$ & $-0.293^{*}$ & 1.000 & & & \\
\hline$\stackrel{\cup}{ }$ & $-0.119^{\text {ns }}$ & $0.286^{*}$ & & $0.102^{\mathrm{ns}}$ & $-0.078^{\text {ns }}$ & $-0.296^{\mathrm{ns}}$ & 1.000 & & \\
\hline $\begin{array}{l}\text { O } \\
\text { F }\end{array}$ & $-0.332^{* *}$ & $0.225^{\mathrm{ns}}$ & & $0.063^{\text {ns }}$ & $-0.208^{\text {ns }}$ & $0.024^{\text {ns }}$ & $0.046^{\mathrm{ns}}$ & 1.000 & \\
\hline 岴 & $-0.516^{\star * * *}$ & $0.079^{\mathrm{ns}}$ & & $0.046^{\mathrm{ns}}$ & $-0.192^{\mathrm{ns}}$ & $0.086^{\mathrm{ns}}$ & $0.142^{\text {ns }}$ & $0.573^{* * * *}$ & 1.000 \\
\hline
\end{tabular}

All analyses are mean \pm standard error of mean (SEM), $N=72$ using DNMRT. * Significant at $p \leq 0.05$, ** Significant at $p \leq 0.01,{ }^{* * *}$ Significant at $p \leq 0.001,{ }^{* * *}$ Significant at $p \leq 0.0001$, and ns Not significant at $p \geq 0.05, H=H a r v e s t ~ T i m e$, Photo=Photosynthetic Rate, Cond=Stomatal Conductance Rate, TChIC=Total Chlorophyll Content, TCC=Total Carbohydrate Content, TPrC=Total Protein Content, TLiC=Total Lipid Content, TPC=Total Phenolic Content, and TFC=Total Flavonoid Content.

\section{Discussion}

This study was conducted with the main aim to examine the effects of rates of $\mathrm{N}$ and $\mathrm{K}$ with increasing plant age at $\mathrm{H}$ time on physiology responses and phytochemical contents of $\mathrm{G}$. procumbens, it is of particular interest to determine the best harvesting time for the maximum total production of secondary metabolite. The interest was also to examine the presence of compound marker for G. procumbens in the selected treatment with high secondary metabolites.

From the analysis of variance, generally it was demonstrated that G. procumbens biochemical analyses of primary and secondary metabolites were significantly $(p \leq 0.01)$ controlled by the interaction among all the factors studied ( $\mathrm{N}, \mathrm{K}$, and plant age at $\mathrm{H}$ time) (Table 1). Photosynthesis as in physiology parameter was affected mainly ( $\mathrm{p} \leq 0.0001)$ by plant age at $\mathrm{H}$ time, and $\mathrm{N}$ and $\mathrm{H}$ time interaction, whilst Cond was profoundly governed by the interactions of all the factors ( $\mathrm{N}, \mathrm{K}$ and plant age at $\mathrm{H}$ time) (Figures 1 and 2 , and Table 1).

Plant growth was significantly affected by plant age at harvest time because there are mechanisms (growth, development, ageing) regulating phase change from juvenility to maturity which has directly influence the capacity for responding to growth signals. Different turnover patterns (supply of nutrient) of 
structural modules can account for the range of plant growth curve (Thomas, 2013). Meanwhile, the biochemical analysis was governed by the interaction of all factors ( $\mathrm{N}$, $\mathrm{K}$ and plant age at $\mathrm{H}$ time) because as plant cells grow, they break down complex, high-molecular-weight carbon and energy sources through the action of catabolic enzymes. The end products of catabolism were reassembled to form primary metabolites (amino acids, carbohydrates, and fatty acids). These biosynthetic products are then assembled into the complex and essential metabolites that give structure and biological function to the plant. These regulations comprise the pathways that make up secondary metabolites. The nutrients and duration of growth serve basic, well-defined, and essential roles in supporting the synthesis and accumulation of metabolites (Hashiguchi et al., 2017). Metabolic pathways of primary metabolism often supply the precursors for secondary metabolism, therefore, factors that influenced primary metabolism will affect secondary metabolism (Drew \& Demain, 1977).

All the physiological (Photo, Cond and TChIC) and biochemical traits (TCC, TPrC, TLiC, TPC and TFC) were markedly influenced by $\mathrm{N}(\mathrm{p} \leq 0.05)$ and $\mathrm{K}(\mathrm{p} \leq 0.01)$ treatments, $\mathrm{H}$ time and the interactions $(\mathrm{p} \leq 0.01)$ between these three factors (Figures 1, 2, 3, 4, 5, 6, 7, and 10). Growth-differentiation balance and carbon-nutrient balance hypothesis indicated that $\mathrm{N}$ and $\mathrm{K}$ affected physiological traits and phytochemical content (primary and secondary metabolite synthesis) (Mohd Zain \& Ismail, 2016). Based on harvest index analysis, NOK30 and N90K0 treatments represent the highest and least effect, respectively on G. procumbens physiology traits and phytochemical content.

The N0K30 was significantly increased TFC compared to control plants (NOK0) ( $p \leq 0.05$ ) by $225 \%$. However, in N90K0, the TFC was decreased by 25\% (Figure 10). Nitrogen as a part of three important coenzymes in the plant cells; ATP, NADPH and Co-A, and $\mathrm{K}$ have influenced the photosynthesis rate and subsequently the metabolite biosynthesis by regulating the respiration for $\mathrm{C}$ skeleton production compounds (Davies et al., 2009).

In quantitative HPLC analysis, phenolic and flavonoid content was high $(0.047$ to $0.179 \mathrm{mg} / \mathrm{mL})$ under moderate rates of $\mathrm{N}$ and $\mathrm{K}$ treatments but decreased $(0.042$ to $0.165 \mathrm{mg} / \mathrm{mL})$ under high rates of $\mathrm{N}$ and $\mathrm{K}$ (Figures 9 and 12). The metabolite content was decreased beyond the optimal point with increasing rate of $\mathrm{N}$ and $\mathrm{K}$ (Wuyts et al., 2015) as shown in NOK30 and N90KO (Figures 4, 5, 6,7 and 10) (Fonseca et al., 2006). A ratio of N:K at 0:30 (NOK30) indicated the plant has optimised for metabolite production at Week 4. However, in $\mathrm{N} 90 \mathrm{~K} 0$, with low $\mathrm{K}$ in relation to $\mathrm{N}$, the metabolite production were decreased (Larbat et al., 2012). Meanwhile, high $\mathrm{K}$ rates in N0K60 and N0K90 was not significantly affecting physiological traits and phytochemical content ( $p \leq 0.05$ ) (Kaiser et al., 2016). The event was due to total reduction of $\mathrm{N}$ content, and consequently $\mathrm{K}$ has lost interaction with $\mathrm{N}$ for metabolite differentiation balance (Pal et al., 2015).

Meanwhile, qualitative and quantitative analysis developed using TLC and HPLC, respectively has markedly caffeic acid and kaempferol as phytochemical markers for phenolic and flavonoid content measurements (Figures 8 and 11).

\section{Conclusions}

The $\mathrm{N}$ and $\mathrm{K}$ affected metabolite content significantly $(\mathrm{p} \leq 0.05)$ with higher effect on physiological traits and biochemical attributes $(p \leq 0.01)$. Harvest index analysis have shown the effect of $N$ and $K$ treatments in the following descending manner, N0K30 > N0K60 > N0K90 > N0K0 > N90K60 > N90K30 > N90K90 $>\mathrm{N} 90 \mathrm{~K} 0$ as explained in growth-differentiation balance and carbon-nutrient balance hypothesis. The results suggest that N0K30 and N90K0 were high and least, respectively, effective for Cond ( $p \leq 0.0001)$ and phytochemical content (TPrc and TLiC, $p<0.01$; TPC and TFC, $p \leq 0.0001$ ). However, not significant in Photo ( $p \geq 0.05$ ). These effects were because $K$ has induced TFC, but decreased TPrC, especially in 0 $\mathrm{kg} / \mathrm{ha} \mathrm{N}$ interaction treatment. As compared to $90 \mathrm{~kg} / \mathrm{ha} \mathrm{N}$ interaction treatment, increases of TFC, and decreases of TPrC have led to plant's oxidative defense mechanism against temperature and $\mathrm{pH}$ stress. These were due to incorporation of $\mathrm{K}$ which alter the growth media and cells intercellular $\mathrm{pH}$ by internal $\mathrm{K}$ balance. Thus, high metabolites content of $\mathrm{G}$. procumbens should be improved through the selection of appropriate $\mathrm{N}$ and $\mathrm{K}$ rates, and plant age at which high total metabolite production can be achieved.

\section{Data availability}

We have presented all our main data in the form of figures and tables. The data sets supporting the conclusions of this article are included within the article. 


\section{Conflicts of interest}

The authors declare that they have no competing interests.

\section{Funding statement}

Financial support for this study was given by Skim Latihan Akademik IPTA, Ministry of Higher Education Malaysia and Universiti Malaysia Sarawak.

\section{Acknowledgments}

The authors would like to thank the Ministry of Higher Education Malaysia, Universiti Malaysia Sarawak, Universiti Putra Malaysia, and Universiti Malaya.

\section{References}

[1] Ali, Z., Ganie, S. H., Narula, A., Abdin, M. Z., \& Srivastava, P. S. (2012). Organic and inorganic fertilizers influence biomass production and esculin content in Cichorium intybus L. Journal of Phytology, 4(5), 55-60.

[2] Aminifard, M. H., Aroiee, H., Nemati, H., Azizi, M., \& Jaafar, H. Z. E. (2012). Fulvic acid affects pepper antioxidant activity and fruit quality. African Journal of Biotechnology, 11(68), 13179-13185.

[3] Anulika, N. P., Ignatius, E. O., Raymond, E. S., Osasere, O.-I., \& Abiola, A. H. (2016). The Chemistry Of Natural Product: Plant Secondary Metabolites. International Journal of Technology Enhancements and Emerging Engineering Research, 4(8), 1.

[4] Armengaud, P., Sulpice, R., Miller, A. J., Stitt, M., Amtmann, A., \& Gibon, Y. (2009). Multilevel Analysis of Primary Metabolism Provides New Insights into the Role of Potassium Nutrition for Glycolysis and Nitrogen Assimilation in Arabidopsis Roots. Plant Physiology, 150(2), 772-785.

[5] Armstrong, D. L. (1998). Better Crops with Plant Food. (D.L. Armstrong \& K. P. Griffin, Eds.), Better Crops with Plant Food (3rd Ed.). Georgia: Potash \& Phosphate Institute.

[6] Ashokkumar, K., Selvaraj, K., \& Saradha Devi, K. M. (2013). Reverse phase-high performance liquid chromatography-diode array detector (RP-HPLC-DAD) analysis of flavonoids profile from curry leaf (Murraya koenigii L.). Journal of Medicinal Plants Research, 7(47), 3393-3399.

[7] Awang, Y., Shaharom, A. S., Mohamad, R. B., \& Selamat, A. (2009). Chemical and Physical Characteristics of Cocopeat-based Media Mixtures and their Effects on the Growth and Development of Celosia cristata. American Journal of Agricultural and Biological Science, 4(1), 63-71.

[8] Baby, S., Johnson, A. J., Zachariah, E. J., \& Hussain, A. A. (2017). Nepenthes pitchers are CO2-enriched cavities, emit CO2 to attract preys. Scientific Reports, 7(1), 1-10.

[9] Bellés, J. M., Garro, R., Pallás, V., Fayos, J., Rodrigo, I., \& Conejero, V. (2006). Accumulation of gentisic acid as associated with systemic infections but not with the hypersensitive response in plant-pathogen interactions. Planta, 223, 500-511.

[10] Caretto, S., Linsalata, V., Colella, G., Mita, G., \& Lattanzio, V. (2015). Carbon Fluxes between Primary Metabolism and Phenolic Pathway in Plant Tissues Under Stress. International Journal of Molecular Sciences, 16, 26378-26394.

[11] Chen, Y., Yu, M., Zhu, Z., Zhang, L., \& Guo, Q. (2013). Optimisation of Potassium Chloride Nutrition for Proper Growth, Physiological Development and Bioactive Component Production in Prunella vulgaris L. PLoS ONE, 8(7), 1-7.

[12] Chrysargyris, A., Drouza, C., \& Tzortzakis, N. (2017). Optimization of potassium fertilization/nutrition for growth, physiological development, essential oil composition and antioxidant activity of Lavandula angustifolia Mill. Journal of Soil Science and Plant Nutrition, 17(2), 291-306.

[13] Davies, M. J., Atkinson, C. J., Burns, C., Woolley, J. G., Hipps, N. A., Arroo, R. R. J., ... Bentley, S. (2009). Enhancement of artemisinin concentration and yield in response to optimization of nitrogen and potassium supply to Artemisia annua. Annals of Botany, 104, 315-323.

[14] Drew, S. W., \& Demain, A. L. (1977). Effect of Primary Metabolites on Secondary Metabolism. Annual Review of Microbiology, 31, 343-356.

[15] Farrell, R. E. (2007). The Regulation of Gene Expression in Plants and Animals. In C. L. Bassett (Ed.), Regulation of Gene Expression in Plants (pp. 1-38). New York: Springer.

[16] Figueiredo, A. C., Barroso, J. G., Pedro, L. G., \& Scheffer, J. J. C. (2008). Factors affecting secondary metabolite production in plants: volatile components and essential oils. Flavour and Fragrance Journal, 23, 213-226.

[17] Fonseca, J. M., Rushing, J. W., Rajapakse, N. C., Thomas, R. L., \& Riley, M. B. (2006). Potential Implications of Medicinal Plant Production in Controlled Environments: The case of Feverfew (Tanacetum parthenium). HortScience, 41(3), 531-535.

[18] Galieni, A., Di Mattia, C., De Gregorio, M., Speca, S., Mastrocola, D., Pisante, M., \& Stagnari, F. (2015). Effects of nutrient deficiency and abiotic environmental stresses on yield, phenolic compounds and antiradical activity in lettuce (Lactuca sativa L.). Scientia Horticulturae, 187, 93-101. 
[19] Giedyk, M. (2011). HPLC as an analytical and preparative method. Warsaw: Polish Academy of Science.

[20] Hansen, J., \& Moller, I. B. (1975). Analysis of starch and soluble sugars with Anthrone reagent. Anal Biochemistry, 68, 87-94.

[21] Hanudin, E., Wismarini, H., Hertiani, T., \& Sunarminto, B. H. (2012). Effect of shading, nitrogen and magnesium fertilizer on phyllanthin and total flavonoid yield of Phyllanthus niruri in Indonesia soil. Journal of Medicinal Plants Research, 6(30), 4586-4592.

[22] Hashiguchi, A., Tian, J., \& Komatsu, S. (2017). Proteomic Contributions to Medicinal Plant Research: From Plant Metabolism to Pharmacological Action. Proteomes, 5(35), 1-12.

[23] Hew, C. S., \& Gam, L. H. (2010). The Identification of High Abundant Proteins in the Leaves of Gynura procumbens. Biotechnology and Biotechnological Equipment, 24(4), 2132-2136.

[24] Heydarizadeh, P. (2016). Photosynthetic Organisms Under Stress. Universite' du Maine.

[25] Hunt, R. (2003). Growth Analysis, Individual Plants. In B. Thomas, D. J. Murphy, \& D. Murray (Eds.), Encyclopaedia of Applied Plant Sciences (Ed., pp. 575-579). London: Academic Press.

[26] Ibrahim, M. H., Ismail, A., Omar, H., Mohd Nadzir, M. N. H., \& Mohd Zain, N. A. (2017). Primary, Secondary Metabolites, Biochemical and Antioxidant Activity of Orthosiphon staminues Benth (Misai Kucing) under Cadmium Exposure. Annual Research \& Review in Biology, 19(1), 1-14.

[27] Ibrahim, M. H., Ismail, A., Omar, H., \& Zain, N. A. M. (2017). Application Effects of Cadmium and Humic Acid on the Growth, Chlorophyll Fluorescence, Leaf Gas Exchange and Secondary Metabolites in Misai Kucing (Orthosiphon stamineus) Benth. Annual Research \& Review in Biology, 18(3), 1-14.

[28] Ibrahim, M. H., \& Jaafar, H. Z. E. (2012). Impact of Elevated Carbon Dioxide on Primary, Secondary Metabolites and Antioxidant Responses of Eleais guineensis Jacq. (Oil Palm) Seedlings. Molecules, 17, 51955211.

[29] Ibrahim, M. H., Jaafar, H. Z. E., Karimi, E., \& Ghasemzadeh, A. (2012). Primary, Secondary Metabolites, Photosynthetic Capacity and Antioxidant Activity of the Malaysian Herb Kacip Fatimah (Labisia Pumila Benth) Exposed to Potassium Fertilization under Greenhouse Conditions. International Journal of Molecular Sciences, 13, 15321-15342.

[30] Ibrahim, M. H., Jaafar, H. Z. E., Karimi, E., \& Ghasemzadeh, A. (2013). Impact of Organic and Inorganic Fertilizers Application on the Phytochemical and Antioxidant Activity of Kacip Fatimah (Labisia pumila Benth). Molecules, 18, 10973-10988.

[31] Ibrahim, M. H., Jaafar, H. Z. E., Karimi, E., \& Ghasemzadeh, A. (2014). Allocation of Secondary Metabolites, Photosynthetic Capacity, and Antioxidant Activity of Kacip Fatimah (Labisia pumila Benth) in Response to CO2 and Light Intensity. The Scientific World Journal, 2014, 1-13.

[32] Ibrahim, M. H., Jaafar, H. Z. E., Rahmat, A., \& Rahman, Z. A. (2011). Effects of Nitrogen Fertilization on Synthesis of Primary and Secondary Metabolites in Three Varieties of Kacip Fatimah (Labisia pumila blume). International Journal of Molecular Sciences, 12, 5238-5254.

[33] Iskander, M. N., Song, Y., Coupar, I. M., \& Jiratchariyakul, W. (2002). Antiinflammatory screening of the medicinal plant Gynura procumbens. Plant Foods for Human Nutrition, 57, $233-244$.

[34] Ismail, A. H., Idris, A. N., Amina, M. M., Ibrahim, A. S., \& Audu, S. A. (2015). Phytochemical studies and thin layer chromatography of leaves and flower extracts of Senna siamea lam for possible biomedical applications. Journal of Pharmacognosy and Phytotherapy, 7(3), 18-26.

[35] Jaafar, H. Z. E., Ibrahim, M. H., \& Fakri, N. F. M. (2012). Impact of Soil Field Water Capacity on Secondary Metabolites, Phenylalanine Ammonia-lyase (PAL), Maliondialdehyde (MDA) and Photosynthetic Responses of Malaysian Kacip Fatimah (Labisia pumila Benth). Molecules, 17(6), 7305-7322.

[36] John, E. C. (1995). Assays for Total Protein. In E. C. John, M. D. Ben, L. P. Hidde, W. S. David, \& T. W. Paul (Eds.), Current Protocols in Protein Science (Ed., pp. 1-24). London: John Wiley \& Sons.

[37] Kaewseejan, N., \& Siriamornpun, S. (2015). Bioactive components and properties of ethanolic extract and its fractions from Gynura procumbens leaves. Industrial Crops and Products, 74, 271-278.

[38] Kaewseejan, N., Sutthikhum, V., \& Siriamornpun, S. (2015). Potential of Gynura procumbens leaves as source of flavonoid-enriched fractions with enhanced antioxidant capacity. Journal of Functional Foods, 12, 120-128. Kaiser, D. E., Rosen, C. J., \& Lamb, J. A. (2016). Potassium for Crop Production.

[40] Khalid, K. A. (2006). Influence of water stress on growth, essential oil, and chemical composition of herbs (Ocimum sp.). International Agrophysics, 20, 289-296.

[41] Kleczewski, N. M., Herms, D. A., \& Bonello, P. (2010). Effects of soil type, fertilization and drought on carbon allocation to root growth and partitioning between secondary metabolism and ectomycorrhizae of Betula papyrifera. Tree Physiology, 30, 807-817.

[42] Krishnan, V., Ahmad, S., \& Mahmood, M. (2015). Antioxidant Potential in Different Parts and Callus of Gynura procumbens and Different Parts of Gynura bicolor. BioMed Research International, 1-7.

[43] Larbat, R., Olsen, K. M., Slimestad, R., Løvdal, T., Bénard, C., Verheul, M., ... Lillo, C. (2012). Influence of repeated short-term nitrogen limitations on leaf phenolics metabolism in tomato. Phytochemistry, 77, 119128.

[44] Latifa, I. C., \& Anggarwulan, E. (2009). Nitrogen content, nitrate reductase activity, and biomass of kimpul (Xanthosoma sagittifolium) on shade and nitrogen fertilizer variation. Nusantara Bioscience, 1(2), 65-71.

[45] Le Bot, J., Bénard, C., Robin, C., Bourgaud, F., \& Adamowicz, S. (2009). The "trade-off" between synthesis of primary and secondary compounds in young tomato leaves is altered by nitrate nutrition: Experimental evidence and model consistency. Journal of Experimental Botany, 60(15), 4301-4314.

[46] Lowry, O. H., Rosebrough, N. J., Farr, A. L., \& Randall, R. J. (1951). Protein Measurement with the Folin Phenol Reagent. Journal of Biological Chemistry, 193(1), 265-275.

[47] Lowry, O. H., Rosebrough, N. J., Farr, A. L., \& Randall, R. J. (2000). Total protein estimation by Lowry's method. Experiment BL 301. Maine: Maine College of Art.

[48] Macadam, J. W., Volenec, J. J., \& Nelson, C. J. (1989). Effects of Nitrogen on Mesophyll Cell Division and Epidermal Cell Elongation in Tall Fescue Leaf Blades'. Plant Physiology, 89, 549-556.

[49] Marchese, J. A., Ferreira, J. F. S., Rehder, V. L. G., \& Rodrigues, O. (2010). Water deficit effect on the 
accumulation of biomass and artemisinin in annual wormwood (Artemisia annua L., Asteraceae). Brazilian Journal of Plant Physiology, 22(1), 1-9.

[50] Mishra, S., Tyagi, A., Singh, I. ., \& Sangwan, R. S. (2006). Changes in lipid profile during growth and senescence of Catharanthus roseus leaf. Brazilian Journal of Plant Physiology, 18(4), 447-454.

[51] Mohamad Bukhori, M. F., Jaafar, H. Z. E., \& Ghasemzadeh, A. (2015). Watering and nitrogen and potassium fertilization: The significance of abiotic control on Gynura procumbens (Lour.) Merr herbs in Malaysia for better growth and secondary metabolite enrichment. Asia Pacific Journal of Molecular Biology and Biotechnology, 23(232), 303-313.

[52] Mohd Zain, N. A., \& Ismail, M. R. (2016). Effects of potassium rates and types on growth, leaf gas exchange and biochemical changes in rice (Oryza sativa) planted under cyclic water stress. Agricultural Water Management, 164, 83-90.

[53] Mohd Zain, N. A., Ismail, M. R., Puteh, A., Mahmood, M., \& Islam, M. R. (2014). Drought Tolerance and lon Accumulation of Rice Following Application of Additional Potassium Fertilizer. Communications in Soil Science and Plant Analysis, 45, 2502-2514.

[54] Mongkhonsin, B., Nakbanpote, W., Hokura, A., Nuengchamnong, N., \& Maneechai, S. (2016). Phenolic compounds responding to zinc and/or cadmium treatments in Gynura pseudochina (L.) DC. extracts and biomass. Plant Physiology and Biochemistry, 109, 549-560.

[55] Morat, N. M. (2013). Total Phenolic and Flavonoid Content of Three Species of Gynura. Universiti Teknologi MARA.

[56] Mori, K., Sugaya, S., \& Gemma, H. (2005). Decreased anthocyanin biosynthesis in grape berries grown under elevated night temperature condition. Scientia Horticulturae, 105, 319-330.

[57] Mráz, P., Tarbush, E., \& Müller-Schärer, H. (2014). Drought tolerance and plasticity in the invasive knapweed Centaurea stoebe s.l. (Asteraceae): Effect of populations stronger than those of cytotype and range. Annals of Botany, 114(2), 1-11.

[58] Ng, H. K., Poh, T. F., Lam, S. K., \& Hoe, S. Z. (2013). Potassium channel openers and prostacyclin play a crucial role in mediating the vasorelaxant activity of Gynura procumbens. BMC Complementary and Alternative Medicine, 13(188), 1-11.

[59] Olkowski, A. A., Amarowicz, R., Peiquiang, Y., Mckinnon, J. J., \& Maenz, D. D. (2003). A Rapid HPLC Method for Determination of Major Phenolic Acids in Plant Material. Polish Journal Of Food And Nutrition Sciences, 12(1), 53-57.

[60] Olszewska, M. (2007). Quantitative HPLC Analysis of Flavonoids and Chlorogenic Acid in the Leaves and Inflorescences of Prunus serotina EHRH. Acta Chromatographica, 19, 253-269.

[61] Ora, O. P., \& Anekwe, G. E. (2013). Lipid composition of medicinal plants: Portulaca oleracea and Ficus thonningi. African Journal of Food Science, 7(5), 76-79.

[62] Ossipov, V., Salminen, J. P., Ossipova, S., Haukioja, E., \& Pihlaja, K. (2003). Gallic acid and hydrolysable tannins are formed in birch leaves from an intermediate compound of the shikimate pathway. Biochemical Systematics and Ecology, 31(1), 3-16.

[63] Ozdal, T., Capanoglu, E., \& Altay, F. (2013). A review on protein-phenolic interactions and associated changes. Food Research International, 51, 954-970.

[64] Pal, P. K., Kumar, R., Guleria, V., Mahajan, M., Prasad, R., Pathania, V., ... Ahuja, P. S. (2015). Crop-ecology and nutritional variability influence growth and secondary metabolites of Stevia rebaudiana Bertoni. BMC Plant Biology, 15(67), 1-16.

[65] Pallez, L. C., \& Dole, J. M. (2001). Maintaining Vegetative Potted Purple Velvet Plants. HortTechnology (Vol. 11). Oklahoma.

[66] Pant, B. D., Pant, P., Erban, A., Huhman, D., Kopka, J., \& Scheible, W. R. (2015). Identification of primary and secondary metabolites with phosphorus status-dependent abundance in Arabidopsis, and of the transcription factor PHR1 as a major regulator of metabolic changes during phosphorus limitation. Plant, Cell \& Environment, 38, 172-187.

[67] Pavloviĉ, A., Singerová, L., Demko, V., \& Hudák, J. (2009). Feeding enhances photosynthetic efficiency in the carnivorous pitcher plant Nepenthes talangensis. Annals of Botany, 104(2), 307-314.

[68] Rahimi, A., Sayadi, F., Dashti, H., \& Tajabadi, A. (2013). Effects of water and nitrogen supply on growth , water-use efficiency and mucilage yield of isabgol (Plantago ovata Forsk). Journal of Soil Science and Plant Nutrition, 13(2), 341-354.

[69] Ramakrishna, A., \& Ravishankar, G. A. (2011). Influence of abiotic stress signals on secondary metabolites in plants. Plant Signaling and Behavior, 6(11), 1720-1731.

[70] Rivai, H., Nurdin, H., Suyani, H., \& Bakhtiar, A. (2011). Karakterisasi Ekstrak Daun Dewa [Gynura pseudochina (L.) DC] Dengan Kromatografi Cair Kinerja Tinggi. Jurnal Farmasi Indonesia, 5(3), 134-141.

[71] Rosidah, Yam, M. F., Sadikun, A., \& Asmawi, M. Z. (2008). Antioxidant potential of Gynura procumbens. Pharmaceutical Biology, 46(9), 616-625.

[72] Sasidharan, S., Chen, Y., Saravanan, D., Sundram, K. M., \& Latha, L. Y. (2011). Extraction, Isolation and Characterization of Bioactive Compounds from Plants Extracts. African Journal of Traditional Complementary \& Alternative Medicine, 8(1), 1-10.

[73] Sasikala, A., Linga Rao, M., \& Savithramma, N. (2013). Quantification of Primary and Secondary Metabolites From Leaves and Stem Bark of Cochlospermum Religiosum (L) Alston. International Research Journal of Pharmacy, 4(8), 228-231.

[74] Selmar, D., \& Kleinwächter, M. (2013). Stress Enhances the Synthesis of Secondary Plant Products: The Impact of Stress-Related Over-Reduction on the Accumulation of Natural Products. Plant and Cell Physiology, 54(6), 817-826.

[75] Seow, L. J., Beh, H. K., Umar, M. I., Sadikun, A., \& Asmawi, M. Z. (2014). Anti-inflammatory and antioxidant activities of the methanol extract of Gynura segetum leaf. International Immunopharmacology, 23, 186-191.

[76] Shams, K. A., Abdel-Azim, N. S., Tawfik, W. A., Hassanein, H. D., Saleh, M. A., \& Hammouda, F. M. (2015) Green extraction techniques: Effect of extraction method on lipid contents of three medicinal plants of 
Apiaceae. Journal of Chemical and Pharmaceutical Research, 7(4), 1080-1088.

[77] Shirazi, O. S., Khan Khattak, M. M. A., Mohd Shukri, N. A., \& Mohd Nur Nasyriq, A. (2014). Determination of total phenolic, flavonoid content and free radical scavenging activities of common herbs and spices. Journal of Pharmacognosy and Phytochemistry, 3(3), 104-108.

[78] Shitan, N. (2016). Secondary metabolites in plants: Transport and self-tolerance mechanisms. Bioscience, Biotechnology and Biochemistry, 80(7), 1283-1293.

[79] Shoeva, O. ., Mock, H. P., Kukoeva, T. V., Börner, A., \& Khlestkina, E. K. (2016). Regulation of the Flavonoid Biosynthesis Pathway Genes in Purple and Black Grains of Hordeum vulgare. PLoS ONE, 11(10), 1-16.

[80] Sim, C. C., Zaharah, A. R., Tan, M. S., \& Goh, K. J. (2015). Rapid Determination of Leaf Chlorophyll Concentration, Photosynthetic Activity and NK Concentration of Elaies guineensis via Correlated SPAD-502 Chlorophyll Index. Asian Journal of Agricultural Research, 9(3), 132-138.

[81] Tamayo, P. R., Weiss, O., \& Sanchez-moreiras, A. M. (2001). Gas Exchange Techniques in Photosynthesis and Respiration Infrared Gas Analyser. In M. J. R. Roger (Ed.), Handbook of Plant Ecophysiology Techniques (Ed., pp. 113-139). Netherlands: Kluwer Academic Publishers.

[82] Teoh, W. Y., Wahab, N. A., Richardson, J. S. ., \& Sim, K. S. (2016). Evaluation of antioxidant properties cytotoxicity and acute oral toxicity of Gynura procumbens (Compositae). Sains Malaysiana, 45(2), 229-235

[83] Thomas, H. (2013). Senescence, ageing and death of the whole plant. New Phytologist, 197(3), 696-711.

[84] Torres, A. P., \& Lopez, R. G. (2010). Commercial Greenhouse Production - Measuring Daily Light Integral in a Greenhouse. Purdue Extension. Purdue.

[85] Treder, J. (2008). The Effects of Cocopeat and Fertilization on the Growth and Flowering of Oriental Lily "Star Gazer." Journal of Fruit and Ornamental Plant Research, 16, 361-370.

[86] Wang, M., Liu, H., Dong, C., Fu, Y., \& Liu, H. (2016). Elevated $\mathrm{CO}_{2}$ enhances photosynthetic efficiency, ion uptake and antioxidant activity of Gynura bicolor DC. grown in a porous-tube nutrient delivery system under simulated microgravity. Plant Biology, 18, 391-399.

[87] Wu, T., Zhou, X., Deng, Y., Jing, Q., Li, M., \& Yuan, L. (2011). In vitro studies of Gynura divaricata (L.) DC extracts as inhibitors of key enzymes relevant for type 2 diabetes and hypertension. Journal of Ethnopharmacology, 136, 305-308.

[88] Wuyts, N., Dhondt, S., \& Inzé, D. (2015). Measurement of plant growth in view of an integrative analysis of regulatory networks. Current Opinion in Plant Biology, 25, 90-97.

[89] Wuyts, N., Palauqui, J. C., Conejero, G., Verdeil, J. L., Granier, C., \& Massonnet, C. (2010). High-contrast three-dimensional imaging of the Arabidopsis leaf enables the analysis of cell dimensions in the epidermis and mesophyll. Plant Methods, 6(17), 1-14.

[90] Yi, X., Zuo, J., Tan, C., Xian, S., Luo, C., Chen, S., ... Luo, Y. (2016). Kaempferol, a flavonoid compound from Gynura medica induced apoptosis and growth inhibition in MCF-7 breast cancer cell. African Journal of Traditional, Complementary and Alternative Medicines, 13(4), 210-215.

[91] Yu, Y., Yang, R., Wan, C., Xu, B., Cao, S., \& Liu, W. (2010). Optimization of Total Flavonoid Compound Extraction from Gynura medica Leaf Using Response Surface Methodology and Chemical Composition Analysis. International Journal of Molecular Sciences, 11, 4750-4763.

[92] Zheng, Z. L. (2009). Carbon and nitrogen nutrient balance signaling in plants. Plant Signaling \& Behavior, $4(7), 584-591$.

[93] Zulkifle, N. (2006). The study of Gynura procumbens (Lour.) Merr. Crude extract using high performance liquid chromatography (HPLC). Universiti Sains Malaysia. 